УДК 581.92

DOI: $10.18101 / 2587-7148-2019-2-15-48$

\title{
КОНСПЕКТ ФЛОРЫ ГАНЗУРИНСКОГО КРЯЖА (ЗАПАДНОЕ ЗАБАЙКАЛЬЕ)
}

\section{А. И. Пяк, М. Б-Ц. Намзалов}

\section{(C) Пяк Андрей Ильич}

доктор биологических наук, профессор

Национальный исследовательский Томский государственный университет, Россия 634050, г. Томск, пр. Ленина, 36

E-mail: a_pyak@list.ru

\section{(C) Намзалов Максар Бимба-Цыренович}

Научный сотрудник, Научный гербарий «Бурятский государственный университет имени Доржи Банзарова», Россия 670000, республика Бурятия, г. Улан-Удэ, ул. Смолина 24а

E-mail: namzmax@gmail.com

В работе представлены основные результаты изучения флоры Ганзуринского кряжа (Селенгинское среднегорье). Дана краткая характеристика физико-географических особенностей и растительности горного массива. В структуре растительного покрова кряжа преобладают сосновые леса — травяные остепненные и экспозиционная горная лесостепь. Наряду с господствующей сосновой лесостепью, встречаются ильмовая горная каменистая лесостепь с Ulmus pumila L. Характерны заросли кустарников из Rosa davurica Pallas, R. acicularis Lindley, Cotoneaster melanocarpus Fischer ex Blytt., Ribes diacantha Pallas. В конспекте содержатся сведения о номенклатуре, условиях обитания и встречаемости по 6 локальным флорам. Аннотированный список содержит 436 видов из 249 родов и 71 семейства. В составе флоры выявлены ряд редких видов, в их числе реликтовые - Allium vodopjanovae N. Friesen, Arctogeron gramineum (L.) DC., Rhamnus erythroxylon Pallas и др., а также эндемичная карагана Caragana buriatica Peschkova. Ключевые слова: вид, Ганзуринский кряж, локальная флора, республика Бурятия, Селенгинское Среднегорье, флора.

\section{Для цитирования:}

А. И. Пяк, М. Б-Ц. Намзалов. Конспект флоры Ганзуринского кряжа (Западное Забайкалье) // Вестник Бурятского государственного университета. Биология, география. 2019. № 1. C. 15-48.

Ганзуринский кряж относится к Селенгинскому Среднегорью (CC) западного Забайкалья. Он составляет северную границу горной системы СС, и примыкает к предгорьям хребта Хамар-Дабан на северо-западе. Расположен Ганзуринский кряж на левобережье реки Селенга и представляет собой типичный горный массив в системе Селенгинского среднегорья. Это природный округ Забайкалья, характеризующийся четко выраженными чертами общности и единства природы, рельефа, климата, почв, растительности и др. (Фадеева, 1960). 
Кряж в виде среднегорного массива тянется вдоль долины реки Селенги. Простирается он с юго-запада на северо-восток на протяжении около 50 км. В наиболее широкой части кряж имеет ширину 19-20 км. Наибольшая абсолютная высота находится в районе урочища Хундэлэн к юго-востоку от села Ключи в 8 километрах, и составляет 1072,9 м. Средние высоты колеблются в пределах 700-800 м над уровнем моря.

Для всего СС характерно чередование низких и средневысотных хребтов и кряжей, обладающих сглаженными водоразделами, и межгорных впадин, ориентированных в северо-восточном, восточно-северо-восточном направлении. Эти главные формы рельефа созданы дифференцированными движениями земной коры, подъемом сложных антиклинальных складок, в результате которого возникли системы гряд плоскогорий и хребтов, опусканием синклиналей, обусловившим образование котловин (Флоренсов, 1948).

Растительность Ганзуринского кряжа в основном представлена сочетанием горных степей со светлохвойными сосновыми лесами. Выделяются следующие пояса растительности: степной, горностепной, лесостепной и лесной, при отсутствии высокогорного пояса, для развития которого нет условий, связанных с невысокими показателями гипсометрии кряжа. При этом размещение растительности зависит от рельефа (экспозиции, крутизны склона), который определяет микро- и мезоклиматические различия в показателях тепла и увлажнения.

В целом, распределение растительности Ганзуринского кряжа на переходе к Иволгинской котловине прослеживаются следующие закономерности. Лесной пояс слабо выражен, слагается сообществами сухих сосняков (мертвопокровно-лишайниковых и травяных остепненных), которые формируются на привершинных участках и во внутренней части кряжа на высотах более 850-900 м.

Ниже они сменяются на обширную полосу предгорной экспозиционной лесостепи - по северному макросклону в пределах высот 700-750 - 900 м, южному — от 850 до 970 м. Однако необходимо отметить факт замещения сосны на ильм приземистый в составе лесного компонента лесостепи в растительности низких сопок (620-700 м.).

Далее, на полого наклонных шлейфах и подгорных равнинах (500-620 м.) доминируют ценозы различных формаций разнотравно-злаковых настоящих степей. В котловине, на древних террасах р. Иволги ландшафтное значение имеют чиевые, леймусовые, пикульниковые солончаковые сообщества и их комплексы в сочетании с пойменными ячменевыми, бескильницевыми, осоковыми лугами с участием зарослей ивняков в прирусловых частях поймы реки.

Основой для работы послужили материалы, собранные автором в течение 2006, 2007, 2010-2012 гг. Собран гербарный материал, включающий более 2000 гербарных листов, сделаны 135 полных геоботанических описаний растительности по общепринятой методике.

Исследование флоры кряжа осуществлялось маршрутным методом и методом конкретных флор А. И. Толмачева $(1931,1986)$ в понимании Б. А. Юрцева (1974, 1975), Л. И. Малышева (1972a, 1975). Работы проведены на 6 ключевых участках, которые названы по географическим названиям урочищ и местностей и соответствуют локальным флорам (Рис. 1): 
1. Локальная флора «Отошо» или Шаманские горы охватывает конечные северо-восточные отроги Ганзуринского кряжа. Высота - 800-900 м.

Рельеф - ассиметричный, по форме осевой гряды. Южные, юго-восточные склоны - крутые и скалистые; северные и северо-восточные - пологие с системой увалов и распадков с небольшими падями к подножиям.

Ландшафт - горная сосновая лесостепь в сочетании с каменистыми степями по вершинам гряд, зарослями кустарников в логах и падях, сухими дерновинно-злаковыми степями на склонах и шлейфах увалов.

2. Локальная флора «Тапхар» включает останцовую гору Тапхар в предгорьях северо-восточного отрога кряжа. Высота - 700-750 м.

Рельеф - плосковершинный останец с крутыми и скалистыми южными склонами, и полого-наклонными увалистыми шлейфами на склонах северных и северо-восточных ориентаций. Выположенная вершина останца $(\mathrm{S}=2000 \mathrm{x} 300$ м) с обилием крупных глыб, развалов горных пород, камней на поверхности.

Ландшафт - горностепной в сочетании с дерновинно-злаковыми настоящими и каменистыми разнотравными степями, зарослями ксерофильных кустарников.

3. Локальная флора «Колобки»-это гряды и системы широких увалов в сочетании с глубокими распадками, пологими балками и эрозионными ложбинами. Высота - 800-950 м.

Рельеф - грядово-увалистый с пологими склонами, нередко сильно разрезанные сетью оврагов от действий временных водотоков, а также зарастающими балками и неглубокими распадками.

Ландшафт - подтаежно-лесной. Это сосняки остепненные (разнотравные, дерновинно-злаковые, кустарниковые, мертвопокровные).

4. Локальная флора «Ключи» - охватывает гряды в окрестностях с. Ключи на западе кряжа.

Рельеф - пологие гряды в сочетании с системами увалов и неглубоких падей.

Ландшафт - подтаежно-лесной. Это сосняки травяные, остепненные в сочетании с зарослями ксеромезофильных кустарников на полянах среди леса.

5. Локальная флора «Уха-Тологой» охватывает скалистые борта и системы краевых гряд вдоль русла р. Селенга в северо-восточной части кряжа. Высота - 800$900 \mathrm{M}$.

Рельеф - крутосклонные гряды со скальными выходами по вершинам в сочетании с узкими ложбинами с развитием русел временных водотоков.

Ландшафт - горно-лесостепной, сухие сосняки в комплексе с разнотравными, кустарниковыми и дерновинно-злаковыми степями.

6. Локальная флора «Янгажино» - юго-западный угол центральной, наиболее облесенной и приподнятой части Ганзуринского кряжа. Высота - 800-1053,7 м.

Рельеф - система вытянутых, разнонаправленных и широких распадков с наивысшей высотной отметкой (1072,9 м.) на месте сочленения нескольких гребневых линий в близи перевала Янгажин.

Ландшафт — подтаежно-лесной в сочетании с горной лесостепью. Сосняки травяные в комплексе с горной сосновой лесостепью, иногда с участием березы и осины, редко - лиственницы сибирской. 
Флора Ганзуринского кряжа включает 436 видов сосудистых растений из 248 родов и 71 семейства.

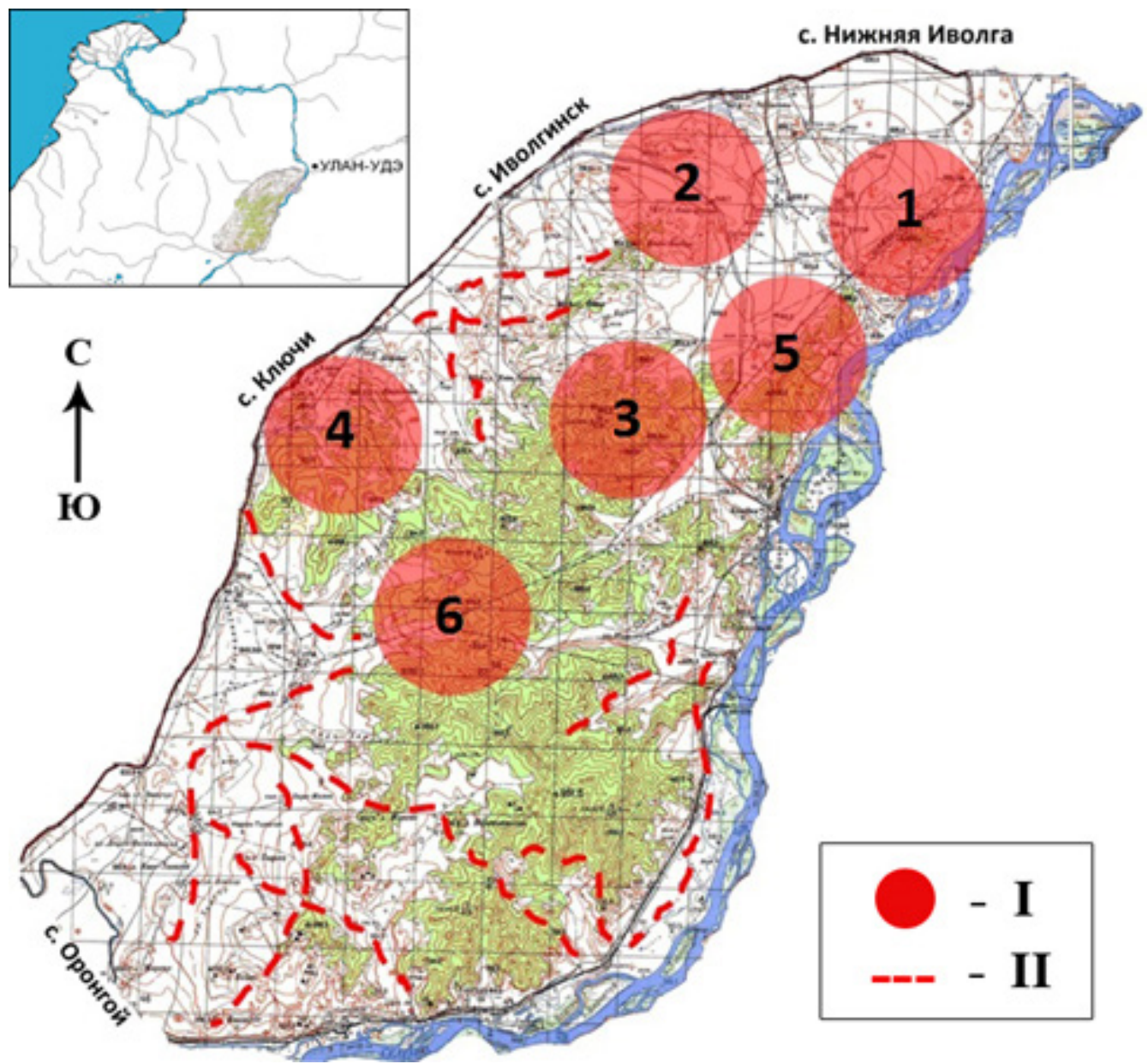

Рис. 1. Схематическая карта Ганзуринского кряжа

I - районы локальных флор: 1 - Отошо (Шаманские горы); 2 - Тапхар; 3 - Колобки; 4 - Ключи; 5 - урочище Ухаа-Тологой; 6 - Янгажино; II — линии маршрутов.

Семейства и рода в конспекте расположены по системе, использованной во Флоре Сибири (1988-2003), а роды и виды внутри родов расположены в порядке букв латинского алфавита. Названия растений даются по Конспекту флоры Азиатской России: Сосудистые растения (2012), за исключением видов, не приведенных в данной работе. Однако, они приводятся по сводке С. К. Черепанова, (1995) и виды рода Carex по Т. В. Егоровой (1999). Приведены синонимы и указаны ссылки по “Флоре Сибири” (1988-2003), “Флоре Забайкалья" (Сергиевская, 1966-1972) и по “Определителю растений Бурятии” (2001).

Для каждого вида указывается латинское название, приведены характерные местообитания, а также условное обозначение локальной флоры, где был отмечен данный таксон. 


\section{Lycopodiaceae - Плауновые (2:2)}

1. Diphasiastrum complanatum (L.) Holub.; Lycopodium complanatum L. - L. anceps Wallr. - Diphasium complanatum (L.) Rothm. - Фл. Сиб., 1, 1988:33; Определитель.., 2001:58.

В лесах, на скалах. Встречается редко в Колобки и Янгажино.

2. Lycopodium clavatum L.; Фл. Сиб., 1, 1988:33; Фл. Заб., 1:49; Определитель.., 2001:57.

По мшистым участкам смешанного леса. Встречается редко в Янгажино.

Selaginellaceae - Плаунковые (Селагинелловые) (1:2)

3. Selaginella rupestris (L.) Spring; Lycopodium rupestre L. - Selaginella rupestris (L.) Spring f. sibirica Milde - S. sibirica (Milde) Hieron - Фл. Сиб., 1, 1988:40; Фл. Заб., 1:52; Определитель.., 2001:59;

На скалах, осыпях, в степях. Встречается в Отошо, Тапхар, Ухаа-Тологой.

4.S. sanguinolenta (L.) Spring; Lycopodium sanguinolentum L. - Фл. Сиб., 1, 1988:40; Фл. Заб., 1:53; Определитель.., 2001:59.

На каменистых склонах, в петрофитных степях. Встречается в Отошо, Тапхар, Колобки и Ухаа-Тологой.

\section{Equisetaceae - Хвощевые (1:4)}

5. Equisetum arvense L.; Фл. Сиб., 1, 1988:43; Фл. Заб., 1:41; Определитель.., 2001:61.

На залежах, в лесах, зарослях кустарников. Встречается в Колобки, Ключи, Янгажино.

6. E. pratense Ehrh.; Фл. Сиб., 1, 1988:46; Фл. Заб., 1:42; Определитель.., 2001:61.

В лесах, зарослях кустарников, каменных россыпях. Встречается повсеместно.

7. E. sylvaticum L.; Фл. Сиб., 1, 1988:47; Фл. Заб., 1:42; Определитель.., 2001:61.

В лесах, зарослях кустарников. Встречается в Колобки, Ключи и Янгажино.

8. E. variegatum Schleich.; Фл. Сиб., 1, 1988:47; Фл. Заб., 1:45; Определитель.., 2001:60.

В лесах, в зарослях кустарников. Встречается в Ключи и Янгажино.

Athyriaceae - Кочедыжниковые (2:2)

9. Diplazium sibiricum (Turcz. ex G. Kunze) Kurata; Фл. Сибири 1:55; Определитель.., 2001:65.

В смешанных лесах, на россыпях камней. Встречается в Янгажино.

10. Cystopteris fragilis (L.) Bernh.; Фл. Сибири 1:56; Фл. Заб. 1: 19; Определитель.., 2001:65.

На скалах, россыпях, в лесах. Встречается в Янгажино.

\section{Woodsiaceae - Вудсиевые (Вудзиевые) (1:2)}

11. Woodsia glabella R.Br.; Фл. Сибири 1:59; Фл. Заб. 1: 18; Определитель.., 2001:66.

На скалах. Встречается в Отошо, Ухаа-Тологой.

12. W. ilvensis (L.) R. Вr.; Фл. Сибири 1:56; Фл. Заб. 1: 18; Определитель.., 2001:66.

На скалах, щебнистых осыпях. Встречается в Отошо, Тапхар, Колобки, УхааТологой. 


\section{Dryopteridaceae - Щитовниковые (2:2)}

13. Dryopteris fragrans (L.) Schott; - Polypodium fragrans L. - Фл. Сибири 1:61; Фл. Заб. 1: 24; Определитель.., 2001:67.

На каменистых осыпях. Встречается в Янгажино.

14. Gymnocarpium dryopteris (L.) Newm.; - Polypodium dryopteris L. - Dryopteris linneana C. Chr. - Фл. Сибири 1:62; Фл. Заб. 1: 26; Определитель.., 2001:68.

В смешанных лесах. Встречается в Колобки и Янгажино.

\section{Sinopteridaceae - Синоптерисовые (1:1)}

15. Cheilanthes argentea (S.G.Gmelin) G. Kunze; Aleuritopteris argentea (S.G.Gmel.) Fee - Фл. Сибири 1:73; Фл. Заб. 1: 33; Определитель.., 2001:70.

В трещинах скал и останцов. Встречается в Тапхар.

Polypodiaceae - Многоножковые (1:1)

16. Polypodium virginatum L.; P. sibiricum Sipl. - Фл. Сибири 1:74; Фл. Заб. 1: 36; Определитель.., 2001:71.

На скалах, каменистых россыпях. Встречается в Тапхар.

\section{Pinaceae - Сосновые (3:4)}

17. Larix sibirica Ledeb.; Фл. Сибири 1:79; Фл. Заб., 1:57; Определитель.., 2001:72.

Встречается единично в смешанных лесах. Колобки и Янгажино.

18. Pinus sibirica DuTour; Фл. Сибири 1:80; Фл. Заб., 1:59; Определитель.., 2001:73.

Встречается единично в смешанных лесах в Янгажино.

19. P. sylvestris L.; Фл. Сибири 1:81; Фл. Заб., 1:61; Определитель.., 2001:73.

Образует чистые и смешанные насаждения. Встречается повсеместно.

20. Picea obovata Ledeb.; Фл. Сибири 1:78; Фл. Заб., 1:56; Определитель.., 2001:72.

Встречается единично в смешанном лесу. Янгажино.

\section{Ephedraceae - Эфедровые (Хвойниковые) (1:2)}

21. Ephedra dahurica Turcz.; Фл. Сибири 1:84; Фл. Заб., 1:66; Определитель.., 2001:74.

В сухих степях и на каменистых склонах. Встречается в Отошо, Тапхар, Колобки, Ухаа-Тологой.

22. E. monosperma С.А.Меу.; Фл. Сибири 1:84; Фл. Заб., 1:65; Определитель.., 2001:74.

По остепненным опушкам, каменистым степям. Встречается в Отошо, Тапхар.

Poaceae (Gramineae) - Мятликовые (Злаковые) (23:45)

23. Elymus excelsus Turcz. ex Griseb.; Фл. Заб., 2:129; Определитель.., 2001:91.

В остепненных лесах, на лесных лугах, степных склонах. Встречается в Колобки, Ключи, Янгажино.

24. E. gmelinii (Ledeb.) Tzvel.; Определитель.., 2001:92.

В сухих лесах, на степных склонах. Встречается в Отошо, Колобки, УхааТологой.

25. E. schrenkianus (Fisher et Meyer) Tzvel.; Определитель.., 2001:92. 
На каменистых склонах. Встречается в Тапхар.

26. E. sibiricus L.; Фл. Сибири 2:29; Фл. Заб., 2:127; Определитель.., 2001:91.

В лесах и зарослях кустарников, как сорное вдоль дорог. Встречается в Ключи.

27. Elytrigia repens (L.) Nevski; Фл. Сибири 2:34; Фл. Заб., 2:123; Определитель.., 2001:95.

В степях, на лугах, полях, залежах. Встречается повсеместно.

28. Agropyron cristatum (L.) Beauv.; Фл. Сибири 2:37; Фл. Заб., 2:124; Определитель.., 2001:96.

В степях, остепненных лесах. Встречается повсеместно.

29. Leymus chinensis (Trin.) Tzvel.; Фл. Сибири 2:46; Определитель.., 2001:100.

На солонцеватых степях, лугах, залежах. Встречается в Колобки, Ключи, Янгажино.

30. Hordeum jubatum L.; Фл. Сибири 2:56; Определитель.., 2001:100.

Сорное. Встречается в Отошо, Колобки, Ключи.

31. Bromopsis inermis (Leysser) Holub.; Фл. Сибири 2:62; Определитель.., 2001:101.

На лугах, лесных полянах, опушках, в луговых степях, среди кустарников, вдоль дорог, рек, по залежам. Встречается в Отошо, Колобки, Ключи, Ухаа-Тологой, Янгажино.

32. B. sibirica (Drobov) Peschkova; B. pumpelliana (Scribn.) Holub. - Фл. Сибири 2:64; Фл. Заб., 2:112; Определитель.., 2001:102.

В лесах, на лесных полянах, остепненных лугах. Встречается в Отошо, Тапхар, Янгажино.

33. Avenula hookeri (Scribner) Holub subsp. schelliana (Hackel) Lomonosova; Helictotrichon schellianum (Hack.) Kitag. - Фл. Сибири 2:69; Фл. Заб., 2:58; Определитель.., 2001:102.

В степях, на каменистых склонах, скалах. Встречается в Тапхар.

34. Trisetum sibiricum Rupr.; Фл. Сибири 2:75; Фл. Заб., 2:55; Определитель.., 2001:104.

В лесах, зарослях кустарников, на лесных полянах. Встречается в Ключи, Янгажино.

35. Koeleria cristata (L.) Pers. s .str.; Фл. Сибири 2:80; Фл. Заб., 2:70; Определитель.., 2001:105.

В степях, на залежах, по обочинам дорог. Встречается в Отошо, Тапхар, Колобки, Ухаа-Тологой.

36. K. glauca (Sprengel) DC.; Фл. Заб., 2:69; Определитель.., 2001:105.

В остепненных сосновых лесах, на опушках. Встречается в Отошо, Колобки, Ухаа-Тологой.

37. Calamagrostis epigeios (L.) Roth.; Фл. Сибири 2:97; Фл. Заб., 2:49; Определитель.., 2001:108.

На лугах, в разреженных лесах. Встречается в Отошо, Колобки, Ухаа-Тологой.

38. Agrostis clavata Trin.; Фл. Сибири 2:107; Фл. Заб., 2:36; Определитель.., 2001:114. 
В лесах, на сырых лугах, в зарослях кустарников, часто вдоль дорог. Встречается в Ключи, Янгажино.

39. A. gigantea Roth.; Фл. Сибири 2: 108; Фл. Заб., 2:38; Определитель.., 2001:113.

На лугах, лесных полянах, зарослях кустарников. Встречается в Ключи, Янгажино.

40. A. trinii Turcz.; Фл. Заб., 2:35; Определитель.., 2001:115.

В степях, на суходольных, остепненных, солонцеватых лугах, лесных полянах. Встречается в Тапхар, Ключи.

41. Hierochloe glabra Trin.; Фл. Сибири 2:117; Фл. Заб., 2:18; Определитель.., 2001:116.

В степях, заходит в леса. Встречается в Отошо.

42. Phleum phleoides (L.) Karsten; Фл. Заб., 2:28; Определитель.., 2001:119.

В степях, осветленных лесах. Встречается в Отошо, Колобки, Ухаа-Тологой.

43. P. pratense L.; Фл. Заб., 2:27; Определитель.., 2001:118.

На лесных и суходольных лугах, у дорог. Встречается в Колобки, Янгажино.

44. Alopecurus pratensis L.; Фл. Сибири 2:128; Фл. Заб., 2:31; Определитель.., 2001:120.

На лугах, по берегам водоемов, среди кустарников. Встречается в Ключи, Янгажино.

45. Festuca lenensis Drobov; Фл. Сибири 2:151; Фл. Заб., 2:102; Определитель.., 2001:127.

На каменистых склонах, скалах, осыпях и галечниках, в каменистых степях. Встречается в Отошо, Тапхар, Ухаа-Тологой.

46. F. dahurica (St.-Yves) V. Krecz. et Bobrov; Фл. Заб., 2:104; Определитель.., 2001:124.

В степи. Встречается в Тапхар.

47. F. pseudovina Hackel ex Wiesb.; Фл. Заб., 2:102; Определитель.., 2001:127.

В разнотравных степях. Встречается в Отошо, Ухаа-Тологой, Янгажино.

48. F. sibirica Hackel ex Boiss; Фл. Заб., 2:97; Определитель.., 2001:122.

На каменистых склонах, скалах. Встречается в Тапхар.

49. Poa angustifolia L.; Фл. Сибири 2:170; Фл. Заб., 2:80; Определитель.., 2001:132.

По суходольным лугам, степным склонам. Встречается в Отошо, Ухаа-Тологой, Янгажино.

50. P. attenuata Trin.; Определитель.., 2001:130.

В степях, на каменистых склонах. Встречается в Отошо, Тапхар, Колобки, УхааТологой, Янгажино.

51. P. botryoides (Trin. ex Griseb.) Roshev; Фл. Сибири 2:135; Фл. Заб., 2:86;

В степях. Встречается в Отошо, Ухаа-Тологой, Янгажино.

52. P. pratensis L.; Фл. Сибири 2:172; Фл. Заб., 2:79; Определитель.., 2001:132.

На лугах, приречных галечниках, лесных полянах, в разреженных лесах и зарослях кустарников. Встречается в Колобки, Ключи, Ухаа-Тологой.

53. P. sibirica Roshev.; Фл. Сибири 2:177; Фл. Заб., 2:77; 
В лесах. Встречается в Ключи, Янгажино.

54. P. stepposa (Krylov) Roshev.; Фл. Сибири 2:185; Фл. Заб., 2:88; Определитель.., 2001:133.

На остепенённых каменистых и щебнистых склонах. Встречается в Отошо, Тапхар, Ухаа-Тологой.

55. Melica nutans L.; Фл. Заб., 2:73; Определитель.., 2001:140.

В лесах, на полянах. Встречается в Колобки, Ухаа-Тологой, Янгажино.

56. M. virgate Turcz. ex Trin; Фл. Заб., 2:71; Определитель.., 2001:140.

На каменистых склонах. Встречается в Отошо, Ухаа-Тологой.

57. Achnatherum sibiricum (L.) Keng. ex Tzvelev; Фл. Сибири 2:220; Определитель.., 2001:141.

В степях, на осветлённых лугах, лесных полянах. Встречается в Отошо, Тапхар, Колобки, Ухаа-Тологой, Янгажино.

58. A. splendens (Trin.) Nevski; Определитель.., 2001:140.

По степным склонам. Встречается в Отошо, Тапхар, Ухаа-Тологой.

59. Stipa baicalensis Roshev.; Определитель.., 2001:142.

В степях, на остепненных лугах, каменистых склонах и скалах. Встречается в Отошо, Тапхар, Ухаа-Тологой.

60. S. grandis P. Smirnov; Определитель.., 2001:142.

В степях. Встречается в Тапхар.

61. S. krylovii Roshev.; Фл. Сибири 2:228; Определитель.., 2001:143.

В степях, на каменистых склонах, лугах. Встречается повсеместно.

62. Cleistogenes squarrosa (Trin.) Keng; Определитель.., 2001:144.

В степях, на каменистых склонах. Встречается в Отошо, Тапхар, Колобки, УхааТологой.

63. C. kitagawae Honda; Определитель.., 2001:144.

На каменистых склонах и скалах, в степях. Встречается в Отошо, Тапхар, УхааТологой.

64. Eragrostis pilosa (L.) Веauv.; Определитель.., 2001:144.

У дорог, на полях, щебнистых склонах. Встречается в Тапхар, Ключи.

65. E. minor Host; Определитель.., 2001:144.

На полях, залежах. Встречается в Ключи, Ухаа-Тологой, Янгажино.

66. Setaria viridis (L.) Веauv.; Определитель.., 2001:145.

Сорное у дорог, на залежах, в степях, по щебнистым склонам. Встречается в Тапхар, Ключи.

67. Spodiopogon sibiricus Trin.; Определитель.., 2001:146.

По степным каменистым склонам и суходольным лугам. Встречается в Отошо, Ухаа-Тологой, Янгажино.

Сурегасеае - Сытевые (2:10)

68. Carex acuta L.; Егорова, 1999:446; Фл. Сибири 3:158; Определитель.., 2001:189.

По берегам водоемов и заводей рек. Обычно образует заросли. Встречается в Ключи, Янгажино.

69. C. argunensis Turcz. ex Trev.; Определитель.., 2001:158. 
В светлых сосновых борах, на остепненных лугах. Встречается в Ухаа-Тологой, Янгажино.

70. C.duriuscula C.A. Meyer; Егорова, 1999:524; Фл. Сибири 3:66; Определитель.., 2001:163.

В степях и на солонцеватых лугах, иногда в сухих светлых сосняках. Встречается в Отошо, Ключи, Ухаа-Тологой.

71. C. korshinskyi Kom.; Егорова, 1999:332; Фл. Сибири 3:133; Определитель.., 2001:182.

В каменистых степях, сухих сосняках, на каменистых склонах. Встречается в Отошо, Тапхар, Ухаа-Тологой.

72. C. lanceolata Boott.; Егорова, 1999:296; Фл. Сибири 3:123; Определитель.., 2001:179.

В сухих лесах. Встречается в Отошо, Ухаа-Тологой.

73. C. macroura Meinsh. s. 1.; Егорова, 1999:290; Фл. Сибири 3:123; Определитель.., 2001:179.

На опушках лесов, каменистых склонах. Встречается в Колобки, Янгажино.

74. C. obtusata Liljeblad; Егорова, 1999:578; Фл. Сибири 3:64; Определитель.., 2001:158.

На остепенённых лугах, сухих каменистых склонах, в сухих светлых лесах и на их опушках. Встречается в Колобки, Янгажино.

75. C. pediformis C.A.Meyer.; Егорова, 1999:291; Фл. Сибири 3:125; Определитель.., 2001:180.

В степях и остепенённых лугах, в сухих лесах, на каменистых склонах. Встречается в Отошо, Колобки, Ключи, Ухаа-Тологой, Янгажино.

76. C. schmidtii Meinsh.; Егорова, 1999:464; Фл. Сибири 3:168; Определитель.., 2001:189.

На сырых и болотистых лугах, в заболоченных березовых лесах и кустарниках. Встречается в Ключи, Янгажино.

77. Kobresia filifolia (Turcz.) Clarke.; Фл. Сибири 3:33; Определитель.., 2001:155.

На лугах, среди кустарников. Встречается Колобки, Ключи, Ухаа-Тологой, Янгажино.

\section{Juncaceae - Ситниковые (1:1)}

78. Luzula pallescens Sw.; Фл. Сибири 4:40; Определитель.., 2001:197.

На лугах, лесных опушках, в осветлённых лесах. Встречается в Отошо, УхааТологой, Янгажино.

\section{Liliaceae - Лилейные (4:15)}

79. Veratrum lobelianum Bernh.; Фл. Сибири, 4:48; Определитель.., 2001:200.

На сырых лугах. Встречается в Ключи, Янгажино.

80. Gagea pauciflora (Turcz. ex Trautv.) Ledeb.; Фл. Сибири, 4: 54; Определитель.., 2001:201.

В степях. Встречается в Колобки, Ухаа-Тологой.

81. Lilium pensylvanicum Ker-Gavler; Фл. Сибири, 4:98; Определитель.., 2001:201. 
На лесных лугах, по опушкам и травянистым склонам. Встречается в Ключи, Янгажино.

82. L. pumilum Delile; Определитель.., 2001:202.

На степных склонах. Встречается в Отошо, Тапхар, Колобки, Ключи, Янгажино. 83. Allium altaicum Pallas; Фл. Сибири, 4:62; Определитель.., 2001:203.

На скалах. Встречается единично в Отошо.

84. A. anisopodium Ledeb.; Фл. Сибири, 4:67; Определитель.., 2001:205.

В степях, на залежах, иногда в сухих сосновых лесах. Встречается в Отошо, Тапхар, Колобки, Ухаа-Тологой.

85. A. bidentatum Fischer ex Prokh; Фл. Сибири, 4:79; Определитель.., 2001:204.

В каменистых степях. Встречается в Отошо, Тапхар, Ухаа-Тологой.

86. A. leисосерhalum Turcz. ex Ledeb.; Фл. Сибири, 4:88; Определитель.., 2001:206.

В песчаных степях, зарослях кустарников. Встречается в Отошо, Тапхар, УхааТологой.

87. A. ramosum L.; Фл. Сибири, 4: 83; Определитель.., 2001:206.

На степных склонах, сухих солонцеватых лугах, в степях. Встречается в Тапхар, Колобки, Янгажино.

88. A. schoenoprasum L.; Фл. Сибири, 4: 64; Определитель.., 2001:203.

На разнотравных, сырых пойменных лугах, в ивовых зарослях. Встречается в Колобки, Ключи, Янгажино.

89. A. senescens L. s. 1.; Фл. Сибири, 4:73; Определитель.., 2001:204.

На каменистых степях, иногда на суходольных лугах. Встречается в Отошо, Тапхар, Ухаа-Тологой.

90. A. splendens Willd. ex Schult. \& Schult.; Фл. Сибири, 4:91; Определитель.., 2001:207.

В светлых лесах, в зарослях кустарников, на каменистых склонах. Встречается в Отошо, Колобки, Ухаа-Тологой.

91. A. stellerianum Willd.; Фл. Сибири, 4:75.

На каменистых степных склонах и скалах. Встречается в Тапхар.

92. A. tenuissimum L.; Фл. Сибири, 4:75; Определитель.., 2001:206.

По каменистым степям. Встречается в Отошо, Тапхар, Колобки, Ухаа-Тологой. 93. A. vodopjanovae Friesen s. str.; Фл. Сибири, 4:77; Определитель... 2001:205;

На каменистых сухих склонах. Встречается в Тапхар.

\section{Hemerocallidaceae - Краснодневовые (1:1)}

94. Hemerocalis minor Miller; Определитель.., 2001:207.

В степях и остепненных лугах. Встречается в Отошо, Колобки, Ухаа-Тологой.

Convalleriaceae - Ландышевые (2:3)

95. Maianthemum bifolium (L.) F. W. Schmidt; Фл. Сибири, 4:108; Определитель.., 2001:208.

В хвойных или смешанных лесах. Встречается в Колобки, Ключи, Янгажино.

96. Polygonatum odoratum (Miller) Druce; Определитель.., 2001:209.

В лесах, на лесных опушках и лугах. Встречается в Отошо, Ухаа-Тологой. 
97. P. sibiricum Delaroche; Определитель... 2001:209;

В лесах, по каменистым склонам. Встречается в Отошо, Ключи, Ухаа-Тологой, Янгажино.

\section{Asparagaceae - Спаржевые (1:1)}

98. Asparagus burjaticus Peschkova; Определитель.., 2001:209.

В степях на каменистых склонах и песках. Встречается в Отошо, Тапхар, Колобки, Ухаа-Тологой.

$$
\text { Trilliaceae - Триллиевые (1:2) }
$$

99. Paris quadrifolia L.; Определитель.., 2001:209.

В березовых лесах. Встречается в Колобки, Янгажино. 100. P. verticillata M. Вieb.; Определитель.., 2001:210.

В смешанных лесах. Встречается в Янгажино.

$$
\text { Iridaceae - Касатиковые (Ирисовые) (1:4) }
$$

101. Iris humilis Georgi; Определитель.., 2001:210.

На сухих лугах и степных, нередко каменистых склонах. Встречается в Колобки, Ухаа-Тологой, Янгажино.

102. I. potaninii Maxim.; Определитель.., 2001:210.

На каменистых склонах и степях. Встречается в Отошо, Ухаа-Тологой.

103. I. ruthenica Ker-Gavl.; Определитель.., 2001:211.

На суходольных лугах, опушках и осветлённых лесах. Встречается в Колобки, Ухаа-Тологой, Янгажино.

104. I. uniflora Pall. ex Link.; Определитель.., 2001:211.

На каменистых склонах и в осветленных лесах. Встречается в Колобки, Ключи, Ухаа-Тологой.

\section{Orchidaceae - Орхидные (Ятрышниковые) (4:4)}

105. Dactylorhiza salina (Turcz. ex Lindley) Soо; Фл. Сибири, 4:132; Определитель.., 2001:215.

На лугах. Встречается в Колобки, Ключи, Янгажино.

106. Neottianthe cucullata (L.) Sclechter; Определитель.., 2001:215.

В хвойных и смешанных лесах. Встречается в Ключи, Янгажино.

107. Goodyera repens (L.) R. Br.; Фл. Сибири, 4:143; Определитель.., 2001:218.

В тенистых лесах. Встречается в Колобки, Янгажино.

108. Platanthera bifolia (L.) Rich.; Определитель... 2001:217; Определитель.., 2001:217.

На лесных полянах, среди кустарников. Встречается в Ключи, Янгажино.

Salicaceae - Ивовые (2:5)

109. Populus tremula L.; Фл. Сибири 5:11; Определитель.., 2001:220.

В лесах, вторична после рубок и пожаров. Встречается в Колобки, Ключи, Янгажино.

110. Salix bebbiana Sarg.; Фл. Сибири 5:29; Определитель.., 2001:229.

Сухие светлые леса. Встречается в Отошо, Колобки, Ухаа-Тологой.

111. S. caprea L.; Фл. Сибири 5:30; Определитель.., 2001:229.

На лугах, в лесах. Встречается в Колобки, Янгажино. 
112.S. microstachya Turcz. ex Trautv.; Определитель.., 2001:224.

В лесу, на берегу реки. Встречается в Ухаа-Тологой.

113. S. taraikensis Kimura; Фл. Сибири 5:31; Определитель.., 2001:232.

В светлых лесах, на вырубках и опушках. Встречается в Отошо, Колобки, УхааТологой.

\section{Betulaceae - Березовые (1:1)}

114. Betula pendula Roth; Фл. Сибири 5:69; Определитель.., 2001:237.

В лесных и лесостепных ценозах, на лугах. Встречается в Отошо, Колобки, Ключи, Ухаа-Тологой, Янгажино.

\section{Ulmaceae - Ильмовые (Вязовые) (1:1)}

115. Ulmus pumila L.; Определитель.., 2001:239.

По песчано-каменистым почвам, степным склонам. Встречается в Отошо, Тапхар, Ухаа-Тологой.

\section{Cannabaceae - Коноплевые (1:1)}

116. Cannabis sativa L.; Фл. Сибири 5:75; Определитель.., 2001:239.

Сорное, близ жилищ, в посевах, по каменистым склонам. Встречается в Тапхар, Колобки, Ухаа-Тологой.

\section{Urticaceae - Крапивные (1:3)}

117. Urtica angustifolia Fisch. ex Hornem; Фл. Сибири 5:77; Определитель.., 2001:240.

В лесах и кустарниках по ключам, сорным местам, у скал, и россыпей. Встречается в Отошо, Ключи, Ухаа-Тологой.

118. U. cannabina L.; Фл. Сибири 5:77; Определитель.., 2001:240.

По сорным местам, близ жилья, пастбищах, на остепненных лугах, по каменистым склонам, среди кустарников. Встречается в Отошо, Ухаа-Тологой.

119. U. dioica L.; Фл. Сибири 5:77; Определитель.., 2001:241.

В лесах, у дорог. На залежах. Встречается в Отошо, Ключи, Ухаа-Тологой, Янгажино.

\section{Santalaceae - Санталовые (1:1)}

120. Thesium saxatile Turcz. ех A. DC; Определитель.., 2001:242.

На горных, каменистых степях. Встречается в Отошо, Ухаа-Тологой.

\section{Polygonaceae - Гречишные (7:10)}

121. Rumex acetosella L.; Фл. Сибири 5:114; Определитель.., 2001:246.

В каменистой степи. Встречается в Ухаа-Тологой.

122. R. thyrsiflorus Fingerh; Фл. Сибири 5:97; Определитель.., 2001:247.

На сухих лугах, степях. Встречается в Колобки, Ухаа-Тологой.

123. Rheum rhabarbarum L.; R. undulatum L. - Определитель.., 2001:247.

На скалах, каменистых склонах. Встречается в Отошо, Ухаа-Тологой.

124. Atraphaxis pungens (Bieb.) Jaub. et Spach; Определитель.., 2001:247.

В зарослях кустарников. Встречается в Отошо, Ключи, Ухаа-Тологой.

125. Bistorta vivipara (L.) S.F. Gray; Фл. Сибири 5:112; Определитель.., 2001:248.

В лесном поясе на лугах. Встречается в Ключи, Янгажино. 
126. Aconogonon alpinum (All.) Schur.; Фл. Сибири 5:120; Определитель.., 2001:251.

На лугах, луговых склонах, по лесным опушкам. Встречается в Колобки, Янгажино.

127. A. angustifolium (Pallas) Нara; Фл. Сибири 5:121; Определитель.., 2001:251.

В степях, на крутых каменистых степных склонах, и остепненных лугах. Встречается в Тапхар, Ухаа-Тологой.

128. A. divaricatum (L.) Nakai ex Mori; Определитель.., 2001:251.

В степях, зарослях кустарников, на остепненных лугах и как сорное в посевах и на залежах. Встречается в Отошо, Колобки, Ухаа-Тологой.

129. Fagopyrum tataricum (L.) Gaertn; Фл. Сибири 5:125; Определитель.., 2001:252.

На залежах, скалах после пожара. Встречается в Ключи.

130. Polygonum aviculare L.; Фл. Сибири 5:127; Определитель.., 2001:254.

На лугах, в лесу. Встречается в Колобки, Ухаа-Тологой.

\section{Chenopodiaceae - Маревые (5:8)}

131. Chenopodium acuminatum Willd.; Определитель.., 2001:257.

На каменистых склонах и залежах. Встречается в Тапхар, Колобки.

132. C. album L.; Фл. Сибири 5: 141; Определитель.., 2001:257.

На мусорных местах, залежах вдоль дорог. Встречается в Тапхар.

133. C. aristatum L.; Teloxys aristata (L.) Moq. - Фл. Сибири 5:143; Определитель.., 2001:256.

По степным и каменистым склонам. Залежи. Встречается в Отошо, Тапхар.

134. Ceratoides papposa Botsch. et Ikonnikov; Krascheninnikovia ceratoides (L.) Guendelst. - Определитель.., 2001:258.

В степи, на склонах. Встречается в Отошо, Ухаа-Тологой.

135. Axyris amaranthoides L.; Фл. Сибири 5:158; Определитель.., 2001:258.

У жилья, в огородах, вдоль дорог. Встречается в Отошо, Янгажино.

136. A. hybrida L.; Фл. Сибири 5: 159; Определитель.., 2001:258.

На степных каменистых склонах, в рудеральных местах. Встречается в Отошо, Ухаа-Тологой.

137. Kochia prostrata (L.) Schraber; Определитель.., 2001:258.

В степях. Встречается в Тапхар, Ухаа-Тологой, Янгажино.

138. Salsola collina Pallas; Определитель.., 2001:261.

Рядом с ключом, в степи. Встречается единично в Ключи.

\section{Caryophyllaceae - Гвоздичные (8:12)}

139. Stellaria dichotoma L.; Определитель.., 2001:266.

На каменистых, щебнистых и песчаных склонах, по скалам. Встречается в Отошо, Тапхар, Колобки, Ухаа-Тологой.

140. S. graminea L.; Определитель.., 2001:268.

В светлых лесах и на лугах. Встречается в Колобки, Ухаа-Тологой.

141. S. media (L.) Villars; Фл. Сибири 6:25; Определитель.., 2001:266.

Близ дорог, в степях. Встречается в Отошо, Тапхар. 
142. Cerastium arvense L.; Фл. Сибири 6:31; Определитель.., 2001:271.

В степях, по сухим склонам. Встречается в Колобки, Ухаа-Тологой. 143. Minuartia verna (L.) Hiern; Фл. Сибири 6:47; Определитель.., 2001:274.

На степных каменистых склонах, лугах. Встречается в Отошо, Ухаа-Тологой. 144. Eremogone meyeri (Fenzl.) Ikonn.; Определитель.., 2001:275.

В щебнистых степях, на скалах и останцах. Встречается в Тапхар, Ухаа-Тологой. 145. E. cappilaris (Poir.) Fenzl.; Определитель.., 2001:275.

На скалах, каменистых осыпях, по каменистым степным склонам. Встречается в Отошо, Тапхар, Ухаа-Тологой.

146. Silene jeniseensis Willd.; Определитель.., 2001:278.

В степях, разреженных лесах, на степных склонах. Встречается в Тапхар, Колобки, Ухаа-Тологой, Янгажино.

147. S. repens Patrin; Фл. Сибири 6:68; Определитель.., 2001:278.

По опушкам лесов. Встречается Колобки, Ключи, Ухаа-Тологой, Янгажино.

148. Lychnis sibirica L.; Фл. Сибири 6:58; Определитель.., 2001:277.

В сухих лесах, кустарниковых зарослях, на лесных опушках, склонах, сухих лугах. Встречается в Ухаа-Тологой, Янгажино.

149. Oberna behen (L.) Ikonn.; Фл. Сибири 6:71; Определитель.., 2001:279.

В лесах, у источника. Встречается в Отошо, Ключи, Янгажино.

150. Dianthus versicolor Fischer ex Link.; Фл. Сибири 6:94; Определитель.., 2001:283.

В степях. Встречается в Отошо, Тапхар, Ухаа-Тологой, Янгажино.

Ranunculaceae - Лютиковые (9:19)

151. Trollius sibiricus Schipcz.; Фл. Сибири 6:108; Определитель.., 2001:65.

По сырым лугам, леса. Встречается в Колобки, Янгажино.

152. Aquilegia buriatica Peschkova; Определитель.., 2001:65.

На останцах, скалах, щебнистых склонах. Встречается в Янгажино.

153. A. sibirica Lam.; Определитель.., 2001:65.

На лесных полянах, в осветленных лесах. Встречается в Колобки, Ключи, Янгажино.

154. Delphinium elatum L.; Фл. Сибири 6:123; Определитель.., 2001:65.

Разнотравные леса. Встречается в Колобки, Ухаа-Тологой.

155. D. grandiflorum L.; Фл. Сибири 6:122; Определитель.., 2001:65.

В степях, на каменистых склонах. Встречается в Тапхар.

156. Aconitum barbatum Pers.; Фл. Сибири 6:132; Определитель.., 2001:65.

В смешанных лесах. Встречается в Колобки, Янгажино.

157. A. septentrionale Koelle; Определитель.., 2001:65.

По лесам и опушкам. Встречается в Ключи, Янгажино.

158. Anemone sylvestris L.; Фл. Сибири 6:144; Определитель.., 2001:65.

В смешанных и сосновых лесах. Встречается в Ключи, Янгажино.

159. Pulsatilla flavescens (Zucc.) Juz.; Фл. Сибири 6:153; Определитель.., 2001:65.

В степях, лесах. Встречается в Колобки, Ухаа-Тологой, Янгажино.

160. P. turczaninovii Krylov et Serg.; Фл. Сибири 6:154; Определитель.., 2001:65.

В степях, остепенённых сосновых лесах. Встречается повсеместно. 
161. Atragene speciosa Weinm.; A. sibirica L. - Фл. Сибири 6:155; Определитель.., 2001:65.

В лесах, каменистых склонах, среди кустарников. Встречается в Колобки, УхааТологой, Янгажино.

162. Ranunculus chinensis Bunge; Определитель.., 2001:65.

На влажных лугах. Встречается в Ключи.

163. R. propinquus С.А.Мeyer; Фл. Сибири 6:190; Определитель.., 2001:65.

В лесах, на лугах. Встречается в Ключи, Янгажино.

164. R. repens L.; Фл. Сибири 6:192; Определитель.., 2001:65. Определитель.., 2001:65.

В лесах. Встречается в Колобки, Ухаа-Тологой, Янгажино.

165. R. sceleratus L.; Фл. Сибири 6:194; Определитель.., 2001:65.

На влажных лугах. Встречается в Янгажино.

166. Thalictrum foetidum L.; Фл. Сибири 6:202; Определитель.., 2001:65.

В осветлённых лесах, по опушкам. Встречается в Колобки, Ухаа-Тологой, Янгажино.

167. T. minus L.; Фл. Сибири 6:203; Определитель.., 2001:65.

В лесах, суходольных лугах. Встречается в Колобки, Ключи, Ухаа-Тологой, Янгажино.

168. T. petaloideum L.; Определитель.., 2001:65.

На суходольных лугах, степях. Встречается в Отошо, Тапхар, Колобки, УхааТологой, Янгажино.

169. T. simplex L.; Фл. Сибири 6:205; Определитель.., 2001:65.

На осветлённых лесах, по опушкам. Встречается в Колобки, Ключи.

Berberidaceae - Барбарисовые (1:1)

170. Berberis sibirica Pallas; Определитель.., 2001:310.

В каменистых степях и в верхней лесной зоне на скалах и останцах.

Встречается в Ухаа-Тологой, Янгажино.

\section{Papaveraceae - Маковые (2:2)}

171. Chelidonium majus L.; Фл. Сибири 7:11; Определитель.., 2001:311.

В лесах, степях, после пожаров и рубок. Встречается в Отошо, Колобки, УхааТологой, Янгажино

172. Papaver nudicaule L.; Фл. Сибири 7:22; Определитель.., 2001:311.

В степях, остепненных сосновых лесах. Встречается в Тапхар, Колобки, УхааТологой.

\section{Нуресоасеае - Гипекойные (1:1)}

173. Hуресоит erectum L.; Определитель.., 2001:314.

В степях. Встречается в Отошо, Ухаа-Тологой.

\section{Brassicaceae - Капустовые (Крестоцветные) (15:23)}

174. Descurainia sophia (L.) Webb ex Plantl; Фл. Сибири 7:62; Определитель.., 2001:323.

Вдоль дорог, на полях. Сорное. Встречается в Тапхар, Ключи. 
А. И. Пяк, М. Б-Ц. Намзалов. Конспект флоры Ганзуринского кряжа (Западное Забайкалье)

175. Sisymbrium heteromallum С.А.Меу.; Фл. Сибири 7:53; Определитель.., 2001:321.

На каменистых склонах. Встречается в Отошо, Ухаа-Тологой.

176. S. loeselii L.; Определитель.., 2001:321.

На остепненных лугах, на залежах. Встречается в Отошо, Ухаа-Тологой, Янгажино.

177. Erysimum canescens Roth; Определитель.., 2001:323.

На каменистых склонах. Встречается в Отошо, Ухаа-Тологой.

178. E. cheiranthoides L.; Фл. Сибири 7:67; Определитель.., 2001:323.

На лесных опушках, в зарослях кустарников, вдоль дорог. Встречается в Колобки.

179. E. flavum (Georgi) Bobrov.; Определитель.., 2001:323.

На скалах, щебнистых склонах, степях, остепненных сосняках. Встречается в Тапхар, Колобки.

180. E. hieracifolium L.; Фл. Сибири 7:324; Определитель.., 2001:65.

На остепненных лугах, в степях. Встречается в Отошо, Тапхар, Ухаа-Тологой.

181. Rorippa palustris (J.P. Bergeret) Schinz et Thell; Фл. Сибири 7:76; Определитель.., 2001:324.

По влажным лугам, сорный. Встречается в Ключи.

182. Arabis pendula L.; Фл. Сибири 7:86; Определитель.., 2001:326.

На залежах. Встречается в Колобки, Ключи.

183. Clausia aprica (Stephan) Korn; Фл. Сибири 7:94; Определитель.., 2001:328.

В степях, остепненных склонах, в разреженных лесах. Встречается в Тапхар.

184. Dontostemon integrifolius (L.) C. А. Меyer; Определитель.., 2001:330.

В степях. Встречается в Колобки, Ухаа-Тологой.

185. D. micrantus C.A. Meyer; Определитель.., 2001:330.

В степях, на залежах. Встречается в Тапхар, Ухаа-Тологой.

186. Berteroa incana (L.) DC.; Определитель.., 2001:330.

Вдоль дорог. Встречается в Отошо, Ухаа-Тологой.

187. Alyssum lenense Adams; Фл. Сибири 7:104; Определитель.., 2001:330.

В степях, в сухих лесах. Встречается в Отошо, Тапхар, Колобки, Ухаа-Тологой. 188. A. obovatum (C.A. Meyer) Turcz.; Фл. Сибири 7:331;

В степях, на каменистых склонах. Встречается в Отошо, Тапхар, Ухаа-Тологой. 189. Ptilotrichum tenuifolium (Stephan ex Willd.) C.A. Меyer; Определитель.., 2001:331.

В сухих каменистых степях. Встречается в Колобки, Ухаа-Тологой.

190. Draba nemorosa L.; Фл. Сибири 7:124; Определитель.., 2001:332.

На лесных опушках, лугах, степных склонах. Встречается в Отошо, УхааТологой.

191. Brassica campestris L.; Фл. Сибири 7:134; Определитель.., 2001:334.

На полях, залежах, сорное. Встречается в Ключи, Янгажино.

192. Lepidium densiflorum Schrader; Фл. Сибири 7:142; Определитель.., 2001:336.

В степях, пустырях, у жилья. Встречается в Тапхар, Ухаа-Тологой.

193. L. ruderale L.; Определитель.., 2001:336. 
В степях. Встречается в Ухаа-Тологой.

194. Thlaspi arvense L.; Фл. Сибири 7:147; Определитель.., 2001:336.

На полях, залежах, пустырях и сорных местах. Встречается в Колобки, УхааТологой.

195. T. cochleariforme DC.; Noccae cochleariformis (DC) A. \& D. Lőve Определитель.., 2001:337.

В степях, на каменистых и щебнистых склонах. Встречается в Отошо, УхааТологой.

196. Capsella bursa-pastoris (L.) Medikus; Фл. Сибири 7:150; Определитель.., 2001:337.

В степях, в лесу, сорное. Встречается в Отошо, Ухаа-Тологой, Янгажино.

Crassulaceae - Толстянковые (2:4)

197. Sedum aizoon L.; Фл. Сибири 7:159; Определитель.., 2001:340.

В остепненных сосновых лесах, среди кустарников. Встречается в Отошо, Тапхар, Ухаа-Тологой.

198. S. telephium L.; Hylotelephium triphyllum (Haw.) Holub. - Фл. Сибири 7:165; Определитель.., 2001:341.

По опушкам смешанных лесов. Встречается в Ключи, Янгажино.

199. Orostachys malacophylla (Pall.) Fisch.; Фл. Сибири 7:167; Определитель.., 2001:341.

В степях, остепенённых лесах. Встречается в Колобки, Ухаа-Тологой, Янгажино. 200. O. spinosa (L.) С.А. Меу.; Фл. Сибири 7:167; Определитель.., 2001:341.

В степи, на скалах и останцах. Встречается в Отошо, Тапхар, Ухаа-Тологой.

Saxifragaceae - Камнеломковые (1:1)

201. Saxifraga spinulosa Adams; Фл. Сибири 7:197; Определитель.., 2001:347.

В осветлённых лесах, по опушкам, на скалах, осыпях. Встречается в Колобки, Ухаа-Тологой, Янгажино.

\section{Grossulariaceae - Крыжовниковые (1:3)}

202. Ribes diacantha Pallas; Определитель.., 2001:350.

На степных склонах, скалах, в остепненных сосновых лесах. Встречается в Тапхар, Колобки, Ухаа-Тологой, Янгажино.

203. R. nigrum L.; Фл. Сибири 7:214; Определитель.., 2001:351.

В лиственничных лесах. Встречается в Янгажино.

204.R. pulchellum Turcz.; Определитель.., 2001:349. На скалах, каменистых склонах, в лесу. Встречается в Колобки, Ухаа-Тологой, Янгажино.

\section{Rosaceae - Розоцветные (17:32)}

205. Spiraea aquilegifolia Pallas; Определитель.., 2001:355.

В горных степях преимущественно по южным склонам, скалах, образует заросли. Встречается в Отошо, Тапхар, Колобки, Ухаа-Тологой, Янгажино.

206. S. media Franz Schmidt; Фл. Сибири 8:18; Определитель.., 2001:356.

В лесах, в зарослях кустарников. Встречается в Тапхар, Колобки, Ключи, УхааТологой, Янгажино.

207. S. salicifolia L.; Фл. Сибири 8:19; Определитель.., 2001:356. 
В лесах. Встречается в Ключи, Янгажино.

208. Cotoneaster melanocarpus Fischer ex Blytt.; Определитель.., 2001:357.

По каменистым степным склонам, в разреженных лесах, по опушкам в кустарниковых зарослях. Встречается в Отошо, Тапхар, Колобки, Ухаа-Тологой, Янгажино.

209. C. mongolicus Pojark.; Определитель.., 2001:358.

На каменистых склонах, среди зарослей кустарников. Встречается в Колобки, Ухаа-Тологой, Янгажино.

210. Malus baccata (L.) Borkh.; Определитель.., 2001:358.

На скалах, останцах среди кустарников. Встречается в Тапхар, Колобки, УхааТологой.

211. Sorbus sibirica Hedl.; Определитель.., 2001:358.

В лесной зоне по останцам, скалам. Встречается в Колобки, Ключи, Янгажино.

212. Crataegus sanguinea Pallas; Фл. Сибири 8:27; Определитель.., 2001:359.

В зарослях кустарников по берегам рек, в осветлённых лесах. Встречается в Колобки, Ключи, Янгажино.

213. Rubus saxatilis L.; Фл. Сибири 8:33; Определитель.., 2001:360.

В лесах. Встречается в Янгажино.

214. Fragaria orientalis Losinsk.; Фл. Сибири 8:34; Определитель.., 2001:361.

По осветлённым лесам, опушкам, травянистым склонам. Встречается в Колобки, Ключи, Ухаа-Тологой, Янгажино.

215. Pentaphylloides fruticosa (L.) O. Schwarz; Фл. Сибири 8:36; Определитель.., 2001:361.

В зарослях кустарников. Встречается в Колобки, Янгажино.

216. Potentilla acaulis L.; Определитель.., 2001:367.

В степях, по опушкам лесов. Встречается в Отошо, Тапхар, Колобки, УхааТологой, Янгажино.

217. P. anserina L.; Фл. Сибири 8:57; Определитель.., 2001:362.

По берегам водоемов, вблизи жилья. Встречается в Ключи, Янгажино.

218. P. bifurca L.; Фл. Сибири 8:48; Определитель.., 2001:362.

В степях, на залежах. Встречается в Тапхар, Колобки, Ключи, Янгажино.

219. P. crebridens Juz.; P. matsuokana subsp. crebridens (Juz.) Sojak Определитель.., 2001:369.

В степях, остепненных сосняках. Встречается в Колобки, Ухаа-Тологой.

220. P. fragarioides L.; Фл. Сибири 8:80; Определитель.., 2001:363.

По разреженным сосновым лесам. Встречается в Колобки, Ухаа-Тологой.

221. P. leucophylla Pallas; Определитель.., 2001:368.

В степях, по каменистым склонам. Встречается в Отошо, Тапхар, Колобки, Ухаа-Тологой.

222. P. longifolia Willd. ex Schlecht; Фл. Сибири 8:66; Определитель.., 2001:364.

В степях, разреженных лесах, по опушкам. Встречается в Колобки, УхааТологой.

223. P. multifida L.; Фл. Сибири 8:51; Определитель.., 2001:366.

В степи, по залежам, вдоль дорог. Встречается в Тапхар, Колобки, Ухаа-Тологой. 
224. P. nudicaulis Willd. Ex Schltdl.; Фл. Сибири 8:56; Определитель.., 2001:365. 225. P. sericea L.; Определитель.., 2001:364.

В степи, по каменистым склонам. Встречается в Тапхар.

226. P. tanacetifolia Willd. ex Schlecht; Фл. Сибири 8:66; Определитель.., 2001:364.

В степях, по лесным полянам, в остепненных сосновых лесах. Встречается в Отошо, Тапхар, Колобки, Ухаа-Тологой, Янгажино.

227. Geum aleppicum Јасq.; Фл. Сибири 8:89; Определитель.., 2001:373.

В разреженных лесах, на лугах. Встречается в Отошо, Тапхар, Ухаа-Тологой, Янгажино.

228. Sibbaldianthe adpressa (Bunge) Juz.; Определитель.., 2001:371.

По каменистым и щебнистым склонам. Встречается в Отошо, Ухаа-Тологой.

229. Chamaerhodos altaica (Laxm.) Вunge; Фл. Сибири 8:86; Определитель.., 2001:372.

В степи по каменисто-щебнистым склонам. Встречается в Отошо, Тапхар, Ухаа-Тологой.

230. C. erecta (L.) Bunge; Определитель.., 2001:372.

В степи. Встречается в Отошо, Тапхар.

231. Filipendula palmata (Pallas) Maxim; Фл. Сибири 8:99; Определитель.., 2001:375.

В разнотравных смешанных лесах. Встречается в Янгажино.

232. Agrimonia pilosa Ledeb.; Определитель.., 2001:376.

В лесах, по суходольным лугам. Встречается в Ключи, Ухаа-Тологой.

233. Sanguisorba officinalis L.; Фл. Сибири 8:123; Определитель.., 2001:376.

На лугах, луговых склонах, в разреженных лесах. Встречается в Отошо, Тапхар, Ухаа-Тологой.

234. Rosa acicularis Lindley; Фл. Сибири 8:125; Определитель.., 2001:377.

В лесах. Встречается повсеместно.

235. R. davurica Pallas; Фл. Сибири 8:126; Определитель.., 2001:377.

В лесах. Встречается Колобки, Ключи, Ухаа-Тологой.

236. Padus avium Miller; Фл. Сибири 8:130; Определитель.., 2001:377.

В лесах, среди кустарников. Встречается в Янгажино.

\section{Fabaceae - Бобовые (15:38)}

237. Lespedeza davurica (Laxm.) Schlinder; Определитель.., 2001:379.

По каменистым склонам, в степях, кустарниках. Встречается в Отошо, УхааТологой.

238. L. juncea (L. fil) Pers.; Определитель.., 2001:379. Встречается в Отошо, Ухаа-Тологой.

В степях, по каменистым склонам, среди степных кустарников.

239. Caragana arborescens Lam.; Фл. Сибири 9:15; Определитель.., 2001:380.

В разреженных лесах, по опушкам, на открытых каменистых склонах. Встречается в Отошо, Ухаа-Тологой, Янгажино.

240. C. buriatica Peschkova; Фл. Сибири 9:15; Определитель.., 2001:380.

В степях. Встречается в Тапхар, Ухаа-Тологой. 
241. C. pygmaea (L.) DC.; Определитель.., 2001:380.

В степях, на скалах. Встречается повсеместно.

242. Astragalus adsurgens Pallas; A. austrosibiricus auct. Non Schischkin - Фл. Сибири 9:57; Определитель.., 2001:385.

На каменистых и щебнистых склонах, в разреженных лесах. Встречается в Тапхар, Колобки, Янгажино.

243. A. chorinensis Bunge; Фл. Сибири 9:38; Определитель.., 2001:382.

В степях, остепненных сосновых лесах. Встречается в Колобки, Ухаа-Тологой. 244. A. danicus Retz.; Фл. Сибири 9:49; Определитель.., 2001:381.

На лесных, суходольных лугах. Встречается в Колобки, Ухаа-Тологой.

245. A. fruticosus Pallas; A. suffruticosus DC. - Фл. Сибири 9:68; Определитель.., 2001:384.

В степях, по опушкам сосновых, лиственничных лесов. Встречается в Отошо, Ухаа-Тологой.

246. A. inopinatus Boriss.; Фл. Сибири 9:57; Определитель.., 2001:385.

На сухих остепненных лугах, в сухих лесах, лесных опушках, среди кустарников.

Встречается в Отошо, Ухаа-Тологой, Янгажино.

247. A. melilotoides Pallas; Определитель.., 2001:381.

В степях, сосновых лесах. Встречается в Колобки, Ухаа-Тологой.

248. A. membranaceus (Fischer) Bunge; Определитель.., 2001:383.

По лугам, луговым степям, лесным опушкам. Встречается в Янгажино.

249. Oxytropis caespitosa (Pallas) Pers.; Фл. Сибири 9:116; Определитель.., 2001:387.

В каменистых степях. Встречается в Колобки и Ухаа-Тологой.

250. O. coerulea (Pall.) DC.; Фл. Сибири 9:86; Определитель.., 2001:386.

На степных каменистых склонах. Единично в Тапхаре.

251. O. glabra (Lam.) DC; Фл. Сибири 9:89; Определитель.., 2001:385.

На лугах, в лесу. Единично в Янгажино.

252. O. lanata (Pall.) DC.; Фл. Сибири 9:129; Определитель.., 2001:390.

В степях. Встречается в Колобки и Ухаа-Тологой.

253. O. myriophylla (Pall.) DC.; Фл. Сибири 9:130; Определитель.., 2001:390.

В степях, сосновых лесах. Встречается в Отошо, Ухаа-Тологой.

254. O. oxyphylla (Pall.) DC.; Фл. Сибири 9:131; Определитель.., 2001:391.

В степях, по каменисто-щебнистым склонам. Встречается в Тапхар, Колобки, Ухаа-Тологой.

255. O. strobilacea Bunge; Фл. Сибири 9:108; Определитель.., 2001:389.

На каменистых склонах, опушках и осветлённых лесах. Единично в УхааТологой.

256. Gueldenstaedtia verna (Georgi) Boriss.; Фл. Сибири 9:151; Определитель.., 2001:391.

На каменистых степных склонах, в сухих сосняках. Встречается единично в Отошо.

257. Glycyrrhiza uralensis Fisch.; Фл. Сибири 9:153 Определитель.., 2001:392. Фл. Заб., 6, 1954:623; 
В степях, в залежах. Встречается в Ключи, Янгажино.

258. Hedysarum alpinum L.; Фл. Сибири 9:155; Определитель.., 2001:392.

В лесах, на лугах. Встречается в Янгажино.

259. Onobrychis arenaria (Kit.) DC.; Определитель.., 2001:393.

В степях, на залежах. Встречается в Колобки, Ключи.

260. Vicia amoena Fisch.; Фл. Сибири 9:173; Определитель.., 2001:395.

По сухим степным склонам, на опушках. Встречается в Отошо, Ухаа-Тологой.

261. V. cracca L.; Фл. Сибири 9:176; Определитель.., 2001:394.

В лесах, опушках, среди кустарников. Встречается в Колобки, Ключи, Янгажино.

262. V. multicaulis Ledeb.; Фл. Сибири 9:179; Определитель.., 2001:395.

По каменистым южным склонам, среди кустарников. Встречается в Отошо, Ухаа-Тологой.

263. V. unijuga А. Вr;; Определитель.., 2001:394.

В смешанных лесах и их пушках. Встречается в Ухаа-Тологой.

264. Lathyrus humilis (Ser.) Sprengel; Определитель.., 2001:396.

В лесах, кустарниковых зарослях. Встречается в Колобки, Ухаа-Тологой, Янгажино.

265. L. pratensis L.; Определитель.,, 2001:396.

На лугах, разреженных лесах, по опушкам. Встречается в Тапхар, Колобки, Янгажино.

266. Melilotus albus Medicus; Определитель.., 2001:397.

На лугах, залежах, вдоль дорог. Встречается в Тапхар, Янгажино.

267. M. suaveolens Ledeb.; Определитель.., 2001:397.

В степях, на залежах, вдоль дорог. Встречается в Ключи, Янгажино.

268. Melilotoides ruthenica (L.) Sojak - Фл. Сибири 9: ; Определитель.., 2001:398. В степях, по каменистым склонам. Встречается в Отошо, Ухаа-Тологой.

269. Medicago falcata L.; Фл. Сибири 9:197; Определитель.., 2001:398.

На суходольных лугах, в степях, на залежах, вдоль дорог. Встречается в Тапхар, Ключи, Янгажино.

270. M. sativa L.; Определитель.., 2001:398.

На лугах, залежах, как сорное. Встречается в Тапхар, Ключи, Янгажино.

271. Trifolium lupinaster L.; Lupinaster pentaphyllus Moench - Фл. Сибири 9:202; Определитель.., 2001:398 .

В остепненных лесах. Встречается в Отошо, Колобки, Ключи, Ухаа-Тологой, Янгажино.

272. T. pratense L.; Определитель.., 2001:399 .

На лугах, в разреженных лесах, на залежах, вдоль дорог. Встречается в Колобки, Ключи, Янгажино.

273. T. repens L.; Определитель.., 2001:399 .

На лугах, опушках. Встречается в Янгажино.

274. Thermopsis lanceolata $\mathrm{R}$. Вr.; Фл. Сибири 9:207; Определитель.., 2001:400.

В степях, по каменистым склонам. Встречается в Тапхар, Ухаа-Тологой. 


\section{Geraniaceae - Гераниевые (2:4)}

275. Geranium pratense L.; Фл. Сибири 10:15; Определитель.., 2001:401.

На лугах, луговых склонах, лесных полянах. Встречается в Ключи, Янгажино.

276. G. sibiricum L.; Фл. Сибири 10:18; Определитель.., 2001:400.

На лугах, в кустарниках, иногда как сорное в степях. Встречается в Отошо, Колобки, Ухаа-Тологой.

277. G. transbaicalicum Serg.; Фл. Сибири 10:19; Определитель.., 2001:402.

На степных склонах, лугах, лесах. Встречается в Ключи, Янгажино.

278. Erodium stephanianum Willd.; Фл. Сибири 10:22; Определитель.., 2001:403.

В степях, на залежах. Встречается в Ключи, Янгажино.

\section{Linaceae - Льновые (1:1)}

279. Linum sibiricum DC.; Фл. Сибири 10: Определитель.., 2001:404.

В степях, по горным южным склонам, остепненным соснякам. Встречается в Колобки, Ухаа-Тологой.

\section{Rutaceae - Рутовые (1:1)}

280. Haplophyllum dauricum (L.) A. Juss.; Определитель.., 2001:405.

На каменистых степных склонах, на вершинах сопок. Встречается в Тапхар, Колобки.

\section{Polygalaceae - Истодовые (1:2)}

281. Polygala sibirica L.; Фл. Сибири 10:37; Определитель.., 2001:406.

В степях, сухих сосновых лесах. Встречается в Колобки, Ухаа-Тологой.

282. P. tenuifolia Willd.; Определитель.., 2001:406.

В каменисто-щебнистых степях, сосновых лесах. Встречается в Отошо, Тапхар, Ухаа-Тологой, Янгажино.

\section{Euphorbiaceae - Молочайные (1:3)}

283. Euphorbia discolor Ledeb.; Фл. Сибири 10:43; Определитель.., 2001:408.

В березовых и смешанных лесах. Встречается в Янгажино.

284. E. virgate Waldst. et Kit.; Фл. Сибири 10:57; Определитель.., 2001:407.

На залежах, гарях. Встречался в Ключи, Янгажино.

\section{Rhamnaceae - Крушиновые (1:1)}

285. Rhamnus erythroxylon Pallas; Определитель.., 2001:409.

На каменистых степных склонах, в зарослях абрикоса сибирского. Встречается в Отошо, Тапхар, Ухаа-Тологой.

\section{Нурегісасеае - Зверобойные (1:1)}

286. Hypericum attenuatum Choisy; Фл. Сибири 10:72; Определитель.., 2001:411.

В луговых степях, на лугах, в березовых и сосновых лесах, по их опушкам. Встречается в Янгажино.

\section{Violaceae - Фиалковые (1:5)}

287. Viola arenaria DC.; Фл. Сибири 10:68; Определитель.., 2001:4015.

В степях, остепненных лесах, на лугах. Встречается в Тапхар, Колобки. 288. V. biflora L.; Определитель.., 2001:415.

В лесах, на каменистых россыпях. Встречается в Отошо, Ухаа-Тологой. 
289. V. dissecta Ledeb.; Фл. Сибири 10:93; Определитель.., 2001:4013.

На лесных опушках. Встречается в Ухаа-Тологой.

290. V. gmeliniana Schult.; Фл. Сибири 10:92; Определитель.., 2001:4013

В сухих сосновых, лиственничных лесах. Встречается в Отошо, Янгажино.

291. V. uniflora L.; Определитель.., 2001:415.

Во влажном смешанном лесу. Встречается в Янгажино.

Onograceae - Кипрейные (Ослинниковые) (1:1)

292. Chamerion angustifolium (L.) Holub.; Chamaenerion angustifolium (L.) Skop.

— Фл. Сибири 10:115; Определитель.., 2001:420.

В лесах, на гарях, вырубках, степных склонах. Встречается повсеместно.

Apiaceae (Umbelliferae) - Сельдерейные (Зонтичные) (9:12)

293.Pleurospermum uralense Hoffm.; Фл. Сибири 10:133; Определитель.., 2001:428.

На лугах, в лесах. Встречается в Колобки, Янгажино.

294. Anthriscus sylvestris (L.) Нoffm.; Определитель.., 2001:428.

В лесах, на лугах. Встречается в Ключи.

295. Bupleurum bicaule Helm.; Определитель.., 2001:429

В каменистых степях. Встречается в Колобки, Ухаа-Тологой.

296. B. scorzonerifolium Willd.; Фл. Сибири 10:145; Определитель.., 2001:430.

В степях, сухих сосновых лесах. Встречается в Тапхар, Ухаа-Тологой, Янгажино. 297. B. sibiricum Vest; Фл. Сибири 10:146; Определитель.., 2001:429

На лесных опушках. Встречается в Ключи, Янгажино.

298. Carum buriaticum Turcz.; Фл. Сибири 10:148; Определитель.., 2001:430.

На степных склонах, лугах.

299. C. carvi L.; Фл. Сибири 10:149; Определитель.., 2001:430.

На лугах, в редкостойных лесах. Встречается в Колобки, Ухаа-Тологой, Янгажино.

300. Angelica tenuifolia (Pallas ex Sprengel) Pimenov; Фл. Сибири 10:179;

Определитель.., 2001:430.

На лугах, в лесах. Встречается в Ключи, Янгажино.

301. Saposhnikovia divaricata (Turcz.) Schischk.; Определитель.., 2001:436.

В степях, по опушкам остепненных лесов. Встречается в Тапхар, Колобки, Ухаа-Тологой.

302. Kitagawia baicalensis (Redow. Ex Willd.) Pimenov; Фл. Сибири 10:184; Определитель.., 2001:436.

На каменистых склонах, в сухих сосняках. Встречается в Тапхар, Ключи, УхааТологой, Янгажино.

303. Heracleum dissectum Ledeb.; Фл. Сибири 10:193; Определитель.., 2001:437. В лесах, кустарниках, на опушках. Встречается в Отошо, Ключи, Янгажино.

304. Peucedanum vaginatum Ledeb.; Определитель.., 2001:437.

В каменистых степях, остепенённых лугах, кустарниках, по лесным опушкам.

Встречается в Янгажино. 


\section{Cornaceae - Кизиловые (1:1)}

305. Swida alba (L.) Opiz.; Фл. Сибири 10:195; Определитель.., 2001:438.

В лесах, в зарослях кустарников. Встречается в Колобки.

\section{Pyrolaceae - Грушанковые (2:3)}

306. Pyrola asarifolia Michaux; P. incarnata (DC.) Freyn - Фл. Сибири 11:9;

В лесах. Встречается в Янгажино.

307. P. rotundifolia L.; Определитель.., 2001:439. Фл. Сибири 11:11;

В лесах. Встречается в Ключи, Янгажино.

308. Orthilia secunda (L.) House; Фл. Сибири 11:12; Определитель.., 2001:439.

В смешанных лесах. Встречается в Ключи, Янгажино.

$$
\text { Ericaceae - Вересковые (2:2) }
$$

309. Rhododendron dauricum L.; Фл. Сибири 11:17; Определитель.., 2001:442.

В лесах, по опушкам. Встречается в Ключи, Янгажино.

310. Vaccinium vitis-idaea L.; Фл. Сибири 11:27; Определитель.., 2001:445.

В сухих хвойных и смешанных лесах. Встречается в Ключи, Янгажино.

\section{Primulaceae - Примуловые (Первоцветные) (2:5)}

311. Androsace filiformis Retz.; Фл. Сибири 11:33; Определитель.., 2001:447.

По лугам, вдоль дорог. Встречается в Тапхар, Янгажино.

312. A. incana Lam.; Фл. Сибири 11:34; Определитель.., 2001:448.

В каменистых, щебнистых степях. Встречается в Тапхар, Янгажино.

313. A. maxima L.; Фл. Сибири 11:35; Определитель.., 2001:447.

В степях, на остепненных лугах. Встречается в Колобки.

314. A. septentrionalis L.; Фл. Сибири 11:36; Определитель.., 2001:447.

На лугах, вдоль дорог, на полях и залежах. Встречается в Тапхар, Ключи.

315. Trientalis europaea L.; Фл. Сибири 11:47; Определитель.., 2001:450.

В лесах. Встречается в Колобки, Ключи, Янгажино.

\section{Limoniaceae - Кермековые (2:2)}

316. Goniolimon speciosum (L.) Вoiss; Фл. Сибири 11:50; Определитель.., 2001:451.

В степях. Встречается в Отошо, Тапхар, Колобки, Ухаа-Тологой.

317. Limonium flexuosum (L.) O. Kuntze; Определитель.., 2001:452.

В степях, преимущественно на щебнистых субстратах. Встречается в Колобки, Ключи..

\section{Gentianaceae - Горечавковые (3:4)}

318. Dasystephana decumbens (L. fil.) Zuev; Gentiana decumbens L. fil. - Фл. Сибири 11:61; Определитель.., 2001:453.

В степях. Встречается в Тапхар, Колобки, Ухаа-Тологой.

319. D. macrophylla (Pallas) Zuev; Gentiana macrophylla Pall. - Фл. Сибири 11:61; Определитель.., 2001:453.

На лугах, в светлых лесах, на лесных полянах. Встречается в Ухаа-ТОлогой, Янгажино.

320. Ciminalis squarrosa (Ledeb.) Zuev; Gentiana squarrosa Ledeb. - Фл. Сибири 11:73; Определитель.., 2001:455. 
В степях. Встречается в Отошо, Ухаа-Тологой.

321. Lomatogonium rotatum (L.) Fries ex Nym; Фл. Сибири 11:82; Определитель.., 2001:457.

В смешанном лесу. Встречается в Янгажино.

Menyanthaceae - Вахтовые (1:1)

322. Menyanthes trifoliate L.; Фл. Сибири 11:85; Определитель.., 2001:458.

По берегу реки. Встречается в Отошо, Ухаа-Тологой.

Asclepiadaceae - Ластовневые (2:2)

323. Cynoctonum purpureum (Pallas) Pobed.; Определитель.., 2001:460.

По сухим скалистым склонам, в степях. Встречается единично в Отошо.

324. Vincetoxicum sibiricum (L.) Decne.; Определитель.., 2001:460.

Сосновые боры, каменистые склоны. Встречается в Отошо, Ухаа-Тологой.

Convolvulaceae - Вьюнковые (1:2)

325. Convolvulus ammanii Desr.; Определитель.., 2001:461.

На сухих щебнистых склонах. Встречается в Отошо, Колобки.

326. C. arvensis L.; Фл. Сибири 11:89; Определитель.., 2001:461.

На полях, залежах, возле дорог. Встречается в Колобки, Ключи.

Polemoniaceae - Синюховые (2:2)

327. Polemonium racemosum (Rigel) Kitamura; P. chinense (Brand) Brand - Фл. Сибири 11:98; Определитель.., 2001:462.

В лесах, на лесных лугах. Встречается в Ключи, Янгажино.

328. Phlox sibirica L.; Фл. Сибири 11:98; Определитель.., 2001:462.

На сухих каменистых склонах, остепненных сосняках. Встречается в Янгажино.

Boraginaceae - Бурачниковые (5:6)

329. Nonea rossica Steven; Фл. Сибири 11:118; Определитель.., 2001:467.

В степях, на залежах, вдоль дорог. Встречается в Ключи.

330. Myosotis imitata Serg.; Фл. Сибири 11:17; Определитель.., 2001:468.

На сухих лугах. Встречается в Отошо, Ухаа-Тологой.

331. Lappula consanguinea (Fischer et Meyer) Guerke; Фл. Сибири 11:134; Определитель.., 2001:469.

В степях, на залежах. Встречается в Ключи, Ухаа-Тологой.

332. L. squarrosa (Retz.) Dumopt.; Фл. Сибири 11:140; Определитель.., 2001:469.

В луговых степях, на залежах. Встречается в Тапхар, Колобки, Ухаа-Тологой.

333. Hackelia deflexa (Wahlenb.) Opiz.; Определитель.., 2001:470.

На каменистых склонах. Встречается в Ухаа-Тологой.

334. Amblynotus rupestris (Pallas ex Georgi) M. Popov ex Serg.; Определитель.., 2001:471.

В каменистых степях. Встречается в Отошо.

Lamiaceae (Labiatae) - Яснотковые (Губоцветные) (11:15)

335. Amethystea coerulea L.; Фл. Сибири 11:160; Определитель.., 2001:475.

На степных склонах. Встречается в Отошо, Тапхар.

336. Scutellaria scordiifolia Fisher ex Schrank; Фл. Сибири 11:164; Определитель.., 2001:475. 
А. И. Пяк, М. Б-Ц. Намзалов. Конспект флоры Ганзуринского кряжа (Западное Забайкалье)

В степях, на каменистых и степных склонах. Встречается в Тапхар.

337. Lophantus chinensis (Rafin.) Bentham; Фл. Сибири 11:167; Определитель.., 2001:476.

В каменистых степях. Встречается в Тапхар, Ухаа-Тологой.

338. Schizonepeta multifida (L.) Brig.; - Nepeta multifida L. - Фл. Сибири 11:168; Определитель.., 2001:477.

На остепненных склонах, среди кустарников. Встречается в Отошо, Тапхар, Ухаа-Тологой, Янгажино.

339. Dracocephalum fruticulosum Stephan; Фл. Сибири 11:175; Определитель.., 2001:478.

В зарослях кустарников, в степи. Встречается в Тапхар.

340. D. foetidum Bunge; D. olchonense Peschkova - Фл. Сибири 11:180; Определитель.., 2001:478.

В степи. Встречается в Тапхар.

341. D. nutans L.; Фл. Сибири 11:179; Определитель.., 2001:478.

На лугах, в степях, светлохвойных и березовых лесах. Встречается в Тапхар, Колобки.

342. Origanum vulgare L.; Определитель.., 2001:483.

В сосновых лесах, на каменистых открытых склонах. Встречается в Отошо, Колобки.

343. Phlomoides tuberosa (L). Moench; Фл. Сибири 11:188; Определитель.., 2001:480.

В луговых степях. Встречается в Тапхар, Колобки, Ухаа-Тологой, Янгажино.

344. Lamium album L.; Определитель.., 2001:480.

На лугах, в лесах и кустарниках, сорничает. Встречается в Ключи, Янгажино.

345. Leonurus mongolicus V. Krecz. et Kuprian.; Определитель.., 2001:481

На скалах, в степи. Встречается в Колобки.

346. L. sibiricus L.; Определитель.., 2001:482.

В степях, по оврагам, щебнистым склонам. Встречается в Колобки, УхааТологой.

347. Panzeria lanata (L.) Sojak; Panzerina lanata(L.) Sojak - Определитель.., 2001:482.

По щебнистым склонам. Встречается в Отошо, Ухаа-Тологой.

348. Thymus baicalensis Serg.; Определитель.., 2001:484.

В каменистых степях. Встречается в Отошо, Ухаа-Тологой.

349. T. mongolicus Ronn.; Фл. Сибири 11:215; Определитель.., 2001:483.

По каменистым склонам, скалам, осыпям. Встречается в Отошо, Тапхар, УхааТологой.

Solanaceae - Пасленовые (2:2)

350. Solanum kitagawae Schonb.-Тіm.; Фл. Сибири 12:10; Определитель.., 2001:486.

На скалах, останцах, щебнистых склонах. Встречается в Тапхар, Колобки, 351. Hyoscyamus niger L.; Фл. Сибири 12:11; Определитель.., 2001:486.

Вдоль дорог, сорное. Встречается в Отошо. 
Scrophulariceae - Норичниковые (6:11)

352. Linaria buriatica Turcz. ex Ledeb.; Определитель.., 2001:489.

В степях, сосновых лесах. Встречается в Отошо.

353. L. vulgaris Miller; Фл. Сибири 12:20; Определитель.., 2001:488.

На каменистых склонах, в сосновом лесу. Встречается в Отошо, Янгажино.

354. Veronica incana L.; Фл. Сибири 12:29; Определитель.., 2001:491.

В каменисто-щебнистых степях. Встречается в Отошо, Тапхар, Ухаа-Тологой, Янгажино.

355. V. longifolia L.; Фл. Сибири 12:27; Определитель.., 2001:491.

На лугах, в лесах. Встречается в Янгажино.

356. Euphrasia hirtella Jordan ex Reuter; Фл. Сибири 12:56; Определитель.., 2001:493.

В лесах по обочине дорог. Встречается в Ключи, Янгажино.

357. E. pectinata Ten.; Фл. Сибири 12:60; Определитель.., 2001:493.

На лугах, лесных полянах. Встречается в Янгажино.

358. Rhinantus vernalis (N. Zinger) Schischkin et Serg.; Фл. Сибири 12:64; Определитель.., 2001:494.

По опушкам соснового леса. Встречается в Отошо.

359. Pedicularis resupinata L.; Фл. Сибири 12:86; Определитель.., 2001:497.

В разреженных лесах. Встречается в Отошо, Ухаа-Тологой.

360. P. rubens Stephan ex Willd.; Фл. Сибири 12:79; Определитель.., 2001:499.

В степях, светлых лесах. Встречается в Тапхар.

361. P. striata Pallas; Определитель.., 2001:498.

В луговых степях, остепненных лесах. Встречается в Янгажино.

362. Cymbaria dahurica L.; Определитель.., 2001:499.

В степях. Встречается в Отошо, Тапхар, Колобки, Ухаа-Тологой.

Orobanchaceae (1:1)

363. Orobanche coerulescens Stephan; Фл. Сибири 12:96; Определитель.., 2001:500.

На степном склоне. Встречается в Тапхар, Колобки.

\section{Plantaginaceae - Подорожниковые (1:3)}

364. Plantago depressa Schlecht.; Фл. Сибири 12:104; Определитель.., 2001:502.

В степях, в остепненных лесах, вдоль дорог. Встречается в Колобки, УхааТологой.

365. P. major L.; Фл. Сибири 12:107; Определитель.., 2001:502.

На лугах, залежах, в лесах. Встречается в Ключи, Янгажино.

366. P. media L.; Фл. Сибири 12:108; Определитель.., 2001:502.

На лугах, в лесах, степях, на залежах. Встречается в Тапхар.

\section{Rubiaceae - Мареновые (2:4)}

367. Galium boreale L.; Фл. Сибири 12:113; Определитель.., 2001:503.

В лесах, среди кустарников, в луговых степях, на опушках лесов. Встречается повсеместно.

368. G. verum L.; Фл. Сибири 12:107; Определитель.., 2001:505. 
А. И. Пяк, М. Б-Ц. Намзалов. Конспект флоры Ганзуринского кряжа (Западное Забайкалье)

В степях, залежах, каменистых склонах. Встречается повсеместно.

369. G. uliginosum L.; Фл. Сибири 12:122; Определитель.., 2001:505.

В лесах. Встречается в Колобки, Ключи, Янгажино.

370. Rubia cordifolia L.; Определитель.., 2001:506.

По каменистым склонам, в кустарниках. Встречается в Отошо, Тапхар, УхааТологой.

\section{Caprifoliaceae - Жимолостные (2:2)}

371. Linnaea borealis L.; Фл. Сибири 12:128; Определитель.., 2001:506.

В лиственничных, еловых, смешанных лесах. Встречается в Янгажино.

372. Lonicera pallasii Ledeb.; Фл. Сибири 12:132; Определитель.., 2001:507.

В смешанных лесах. Встречается в Янгажино.

Valerianaceae - Валериановые (2:3)

373. Patrinia rupestris (Pall.) Dufr.; Фл. Сибири 12:134; Определитель.., 2001:508.

В степях, на каменистых склонах. Встречается в Отошо, Тапхар, Ухаа-Тологой, Янгажино.

374. P. sibirica (L.) Juss.; Определитель.., 2001:508.

На скалах и осыпях по склонам гор. Встречается в Отошо.

375. Valeriana alternifolia Ledeb.; Фл. Сибири 12:137; Определитель.., 2001:509.

На лугах, в лесах. Встречается в Ключи, Янгажино.

\section{Dipsacaceae - Ворсянковые (1:2)}

376. Scabiosa comosa Fischer ex Roem. et Schultes.; Определитель.., 2001:510.

В степях, залежах, по сухим остепненным лесам. Встречается в Отошо, Тапхар.

377. S. ochroleuca L.; Фл. Сибири 12:144; Определитель.., 2001:510.

На опушках леса, вдоль дороги в лесостепи. Встречается в Колобки, УхааТологой.

\section{Campanuliaceae - Колокольчиковые (2:2)}

378. Campanula glomerata L.; Фл. Сибири 12:152; Определитель.., 2001:511.

На лугах, лесных опушках, в кустарниковых зарослях. Встречается в Отошо, Ухаа-Тологой.

379. Adenophora stenanthina (Ledeb.) Kitag.; Определитель.., 2001:513.

По остепненным суходольным лугам. Встречается в Тапхар, Колобки, УхааТологой, Янгажино.

Asteraceae (Compositae) - Астровые (Сложноцветные) (31:57)

380. Solidago dahurica Kitag.; Фл. Сибири 13:18; Определитель.., 2001:521.

В лесах, зарослях кустарников. Встречается в Отошо, Колобки, Ухаа-Тологой, Янгажино.

381. Heteropappus altaicus (Willd.) Novopokr.; Определитель.., 2001:521.

В каменисто-щебнистых степях. Встречается в Отошо, Тапхар, Янгажино.

382. H. biennis (Ledeb.) Tamamsch. ex Grub.; Фл. Сибири 13:23; Определитель.., 2001:521.

В степях, на залежах. Встречается в Колобки, Ухаа-Тологой.

383. Aster alpinus L.; Фл. Сибири 13:24; Определитель.., 2001:522. 
По скалам, каменистым и щебнистым склонам. Встречается в Отошо, УхааТологой.

384. Arctogeron gramineum (L.) DC.; Определитель.., 2001:522.

В каменисто-щебнистых (петрофитных) степях. Встречается в Отошо, Тапхар. 385. Erigeron acris L.; Фл. Сибири 13:38; Определитель.., 2001:523.

На лугах, лесах. Встречается в Ключи, Янгажино.

386. Antennaria dioica (L.) Gaertn.; Фл. Сибири 13:44; Определитель.., 2001:524.

В лесах. Встречается в Колобки, Ключи, Ухаа-Тологой.

387. Leontopodium leontopodioides (Willd.) Вeauverd.; Определитель.., 2001:525.

В степях, на опушках, остепненных сосновых ласах. Встречается в Отошо, Тапхар, Ключи, Ухаа-Тологой, Янгажино.

388. Inula britannica L.; Фл. Сибири 13:52; Определитель.., 2001:526.

На лугах, обочинах дорог. Встречается в Ключи, Янгажино.

389. Achillea asiatica Serg.; Фл. Сибири 13:65; Определитель.., 2001:528.

На лугах, в степях, у дорог. Встречается в Отошо, Ухаа-Тологой, Янгажино.

390. Ptarnica salicifolia (Bess.) Serg.; Фл. Сибири 13:72; Определитель.., 2001:528.

В пойме реки. Встречается в Отошо.

391. Leucanthemum vulgare Lam.; Определитель.., 2001:529.

На лесных полянах, в смешанных лесах. Встречается в Колобки, Ухаа-Тологой. 392. Tanacetum vulgare L. s. str.; Фл. Сибири 13:81; Определитель.., 2001:529.

На лугах, в лесах. Встречается в Отошо, Колобки, Ухаа-Тологой, Янгажино.

393. Dendranthema zawadskii (Herbich.) Tzvel. s. str.; ФЛ. Сибири 13:88; Определитель.., 2001:530.

Каменистые склоны, лесные опушки. Встречается в Отошо, Ухаа-Тологой, Янгажино.

394. Filifolium sibiricum (L.) Kitam.; Определитель.., 2001:531.

Остепненные сосновые леса, каменисто-щебнистые степи. Встречается в Тапхар, Ключи, Янгажино.

395. Artemisia adamsii Bess.; Фл. Сибири 13:104; Определитель.., 2001:533.

Степи, каменистые склоны. Встречается в Отошо, Колобки, Ухаа-Тологой. 396. A. commutata Bess.; Фл. Сибири 13:134; Определитель.., 2001:536.

В степях, сосновых лесах. Встречается в Отошо, Ключи, Ухаа-Тологой, Янгажино.

397. A. dolosa Krasch.; Фл. Сибири 13:134; Определитель.., 2001:535.

Каменистые степи. Встречается в Отошо, Тапхар, Ухаа-Тологой.

398. A. dracunculus L.; Фл. Сибири 13:129; Определитель.., 2001:535.

Остепненные луга, опушки лесов. Встречается в Ухаа-Тологой, Янгажино.

399. A. frigida Willd.; Фл. Сибири 13:119; Определитель.., 2001:534.

В степях. Встречается в Отошо, Тапхар, Колобки, Ухаа-Тологой, Янгажино.

400. A. glauca Pall. ех Willd.; Определитель.., 2001:534.

По остепненным склонам. Встречается в Колобки, Ухаа-Тологой.

401. A. gmelinii Web. ex Stechm.; Фл. Сибири 13:104; Определитель.., 2001:533. 
В степи, на скалах, среди кустарниковых зарослей. Встречается в Тапхар, УхааТологой, Янгажино.

402. A. laciniata Willd.; Фл. Сибири 13:109; Определитель.., 2001:539.

В степях. Встречается в Отошо, Тапхар.

403. A. leucophylla (Bess.) Turcz. ex Clarke; Фл. Сибири 13:100; Определитель.., 2001:540.

В степях. Встречается в Отошо, Тапхар, Ухаа-Тологой.

404. A. rupestris L.; Фл. Сибири 13:123; Определитель.., 2001:537.

В степях. Встречается в Тапхар, Колобки, Ухаа-Тологой.

405. A. rutifolia Steph. ex Spreng.; Определитель.., 2001:534.

На скалах, каменистых россыпях. Встречается в Отошо.

406. A. scoparia Waldst. et Kit.; Фл. Сибири 13:137; Определитель.., 2001:531.

В степях, лугах, остепненных лесах, залежах. Встречается в Отошо, Колобки, Ухаа-Тологой.

407. A. sericea Web. ex Stechm.; Фл. Сибири 13:121; Определитель.., 2001:537.

Леса, луга. Встречается в Отошо, Ухаа-Тологой, Янгажино.

408. A. sieversiana Willd.; Фл. Сибири 13:128; Определитель.., 2001:532.

В степи, залежах. Встречается в Ключи, Янгажино.

409. A. tanacetifolia L.; Фл. Сибири 13:112; Определитель.., 2001:539.

Светлые леса, опушки, заросли кустарников. Встречается в Отошо, Ухаа-

Тологой.

410. A. vulgaris L.; Фл. Сибири 13:103; Определитель.., 2001:540.

В лесах, на опушках, залежах, дорогах. Встречается в Ключи, Янгажино.

411. Neopallasia pectinata Poljak.; Определитель.., 2001:540.

В каменисто-щебнистых степях, у дорог. Встречается в Колобки, Ухаа-Тологой.

412. Cacalia hastata L.; Фл. Сибири 13:150; Определитель.., 2001:542.

В лесах. Встречается в Колобки, Ключи, Янгажино.

413. Senecio campestre (Retz.) DC; Tephroseris integrifolia (L.) Holub - Фл. 13:155; Определитель.., 2001:544;

В сосновых, смешанных лесах. В степях. Встречается в Тапхар, Ухаа-Тологой, Янгажино.

414. S. nemorensis L.; S. octoglossus DC.; - Фл. Сибири 13:167; Определитель.., 2001:545.

В лесах, на опушках, в кустарниках. Встречается в Колобки, Ухаа-Тологой, Янгажино.

415.S. vulgaris L.; Фл. Сибири 13:169; Определитель.., 2001:544.

Сорное, на пустырях, залежах. Встречается в Отошо, Тапхар, Ухаа-Тологой,.

416. Echinops latifolius Tausch.; E. dahuricus Fisch. - Фл. Сибири 13:177;

Определитель.., 2001:546.

В степях. Встречается в Тапхар, Колобки, Ухаа-Тологой, Янгажино.

417. Saussurea elongate DC; Фл. Сибири 13:201; Определитель.., 2001:549.

В лесах. Встречается в Отошо, Ухаа-Тологой.

418. S. salicifolia (L.) DC; Фл. Сибири 13:193; Определитель.., 2001:548.

В степях. Встречается в Тапхар, Колобки, Ухаа-Тологой, Янгажино. 
419. Carduus nutans L.; Фл. Сибири 13:55; Определитель.., 2001:551.

У дорог, жилья, на залежах, нарушенных местообитаниях. Встречается в Ключи. 420. Cirsium setosum (Willd.) Bess.; C. arvense (L.) Scop.; Breea setosa (Willd.) Sojak. - Фл. Сибири 13:221; Определитель.., 2001:551.

По опушкам, в кустарниковых зарослях. Встречается в Ухаа-Тологой.

421. Serratula centauroides L. s. str.; Определитель.., 2001:552.

В степи. Встречается в Отошо, Тапхар, Ухаа-Тологой.

422. Rhaponticum uniflorum (L.) DC; Stemmacanta uniflora (L.) M. Dittrich Определитель.,, 2001:553.

В разнотравно-злаковой степи. Встречается единично в Отошо.

423. Scorzonera austriaca Willd.; Фл. Сибири 13:243; Определитель.., 2001:554.

В степях. Встречается в Отошо, Тапхар, Ухаа-Тологой, Янгажино.

424. S. glabra Rupr.; Фл. Сибири 13:243; Определитель.., 2001:554.

На скалах, каменистых склонах. Встречается в Отошо, Ухаа-Тологой.

425. S. radiata Fischer; Фл. Сибири 13:247; Определитель.., 2001:554.

В каменистой степи. Встречается в Тапхар.

426. Sonchus arvensis L.; Фл. Сибири 13:254; Определитель.., 2001:556.

На залежах, у дорог, на лугах. Встречается в Ключи и Янгажино.

427. Lactuca sibirica (L.) Benth. ex Maxim.; Фл. Сибири 13:318; Определитель.., 2001:556.

На лугах, лесах. Встречается в Колобки, Ключи, Янгажино.

428. Youngiatenuifolia (Willd.) Babc. et Stebb.; Фл. Сибири 13:260; Определитель.., 2001:557.

В степях. Встречается в Отошо,Тапхар, Ухаа-Тологой, Янгажино

429. Taraxacum dissectum Ledeb.; Фл. Сибири 13:277; Определитель.., 2001:558.

В степях. Встречается в Тапхар, Колобки, Ухаа-Тологой.

430. T. officinale Wigg.; Фл. Сибири 13:287 Определитель.., 2001:560.

Поля, залежи. Встречается в Ключи и Янгажино.

431. Crepis bungei Ledeb.; Фл. Сибири 13:300; Определитель.., 2001:563.

На лугах, среди кустарников, в лесах. Встречается в Отошо и Ключи.

432. C. crocea (Lam.) Babc.; Hieracium croceum Lam. - Фл. Сибири 13:302;

Определитель.., 2001:563.

В степях. Встречается в Колобки и Ухаа-Тологой.

433. C. sibirica L.; Определитель.., 2001:562.

В лесах, на опушках, лугах, полянах. Встречается в Янгажино.

434. C. tectorum L.; Фл. Сибири 13:307; Определитель.., 2001:563.

На полях, залежах, у дорог. Встречается в Ключи и Янгажино.

435. Hieracium robustum Fr.; Фл. Сибири 13:315; Определитель.., 2001:564.

На лугах, степях, кустарниковых зарослях, в лесах. Встречается в Колобки, Ухаа-Тологой, Янгажино.

436. H. umbellatum L.; Фл. Сибири 13:318; Определитель.., 2001:565.

В лесах, на лугах. Встречается в Ключи и Янгажино. 
А. И. Пяк, М. Б-Ц. Намзалов. Конспект флоры Ганзуринского кряжа (Западное Забайкалье)

Исследования проведены при поддержке гранта Бурятского государственного университета № 19-10-0502

\section{Литература}

1. Егорова T. B. Осоки (Carex L.) России и сопредельных государств (в пределах бывшего СССР). СПб: Санкт-Петерб. Гос. Хим.-фарм. Академия; Сент-Луис: Миссурийский бот. Сад, 1999. 772 с.

2. Конспект флоры Азиатской России: сосудистые растения / Л. И. Малышев [и др.]; под ред. К. С. Байкова. Новосибирск: Изд-во СО РАН, 2012. 640 с.

3. Малышев Л. И. Площадь выявления флоры в сравнительно-флористических исследованиях // Бот. журн. 1972а. Т. 57, №2. С. 182-197.

4. Малышев Л. И. Количественный анализ флоры: пространственное разнообразие, уровень видового богатства и репрезентативность участков обследования // Бот. журн. 1975. Т. 60, №11. С. 1537-1550.

5. Определитель растений Бурятии / Аненхонов О. А., Пыхалова Т. Д., Осипов К. И., Сэкулич И. Р., Бадмаева Н. К., Намзалов Б. Б. и др. Улан-Удэ, 2001. 672 с

6. Пешкова Г. А. Степная флора Байкальской Сибири. М.: Наука, 1972а. 207 с.

7. Сергиевская Л. П. Флора Забайкалья. Томск: Изд-во Томск. ун-та, 1966-1972. Вып. 1-4.

8. Толмачев А. И. К методике сравнительно-флористических исследований. Понятие о флоре в сравнительной флористике // Журн. Рус. бот. о-ва. 1931. Т. 16, № 1. С. 111-124.

9. Толмачев А. И. Методы сравнительной флористики и проблемы флорогенеза. Новосибирск: Наука. Сиб. отд-ние, 1986. 197 с.

10. Фадеева Н. В. Селенгинское Среднегорье. Улан-Удэ: Бурят. кн. изд-во, 1960. 169 с.

11. Флора Сибири / Под ред. Л. И.Малышева. Новосибирск: Наука, Сиб. отд-ние, 19871997. T. $1-13$.

12. Флоренсов Н. А. Геоморфология и новейшая тектоника Забайкалья // Изв. АН СССР, сер. геол., 1948. №2

13. Черепанов С. К. Сосудистые растения России и сопредельных государств. СПб: Мир и семья, 1995. 992 с.

14. Юрцев Б. А. Дискуссия на тему «Метод конкретных флор в сравнительной флористике» // Бот. журн. 1974. Т. 59. №9. С. 1399-1407.

15. Юрцев Б. А. Некоторые тенденции развития метода конкретных флор // Бот. журн. 1975. T. 60. №1. C. 69-83.

\section{THE CHECK-LIST OF VASCULAR FLORA OF THE GANZURINSK RIDGE (WESTERN TRANSBAIKALIA)}

\section{A. I. Pyak, M. B-Ts. Namzalov}

\section{Pyak Andrey Ilyich}

Doctor of Biology science, professor

National research Tomsk state university, Russia, 634050, Tomsk, 36 Lenin ave.

E-mail: a_pyak@list.ru

\section{Namzalov Maksar Bimba-Tsyrenovich}

Research associate of laboratory "Science herbarium"

Banzarov Buryat State University, Russia, 670000, Ulan-Ude, 24a Smolina st.

E-mail: namzmax@gmail.com 
The article presents the main results of studying the flora of the Ganzurinsk ridge (Selenga middle mountains). A brief description of the physiographic features and vegetation of the mountain range is given. In the structure of the vegetation cover of the ridge pine forests are dominates - grass steppe and exposure mountain forest steppe. Along with the dominant pine forest-steppe, there are elm mountain rocky forest-steppe with Ulmus pumila $\mathrm{L}$. The thickets of bushes from Rosa davurica Pallas, R. acicularis Lindley, Cotoneaster melanocarpus Fischer ex Blytt. and Ribes diacantha Pallas are characteristic.The check-list contains information about the nomenclature, habitat conditions and occurrence rates of 6 local floras. The annotated list contains 437 species from 249 genus and 73 families. A number of rare species were found in the flora, including relict species - Allium vodopjanovae N. Friesen, Arctogeron gramineum (L.) DC., Rhamnus erythroxylon Pallas and others, as well as the endemic Caragana buriatica Peschkova.

Keywords: species, Ganzurinsk ridge, local flora, republic of Buryatia, Selenga middle mountains, flora. 